\title{
Application of a computationally efficient method to approximate gap model results with a probabilistic approach
}

\author{
M. Scherstjanoi ${ }^{1}$, J. O. Kaplan ${ }^{2}$, and H. Lischke ${ }^{1}$ \\ ${ }^{1}$ Dynamic Macroecology, Landscape Dynamics, Swiss Federal Research Institute WSL, Zürcherstr. 111, \\ 8903 Birmensdorf, Switzerland \\ ${ }^{2}$ University of Lausanne, Géopolis, Quartier Mouline, Institute of Earth Surface Dynamics, 1015 Lausanne, Switzerland \\ Correspondence to: M. Scherstjanoi (marc.scherstjanoi@wsl.ch)
}

Received: 16 January 2014 - Published in Geosci. Model Dev. Discuss.: 28 February 2014

Revised: 9 June 2014 - Accepted: 11 June 2014 - Published: 24 July 2014

\begin{abstract}
To be able to simulate climate change effects on forest dynamics over the whole of Switzerland, we adapted the second-generation DGVM (dynamic global vegetation model) LPJ-GUESS (Lund-Potsdam-Jena General Ecosystem Simulator) to the Alpine environment. We modified model functions, tuned model parameters, and implemented new tree species to represent the potential natural vegetation of Alpine landscapes. Furthermore, we increased the computational efficiency of the model to enable area-covering simulations in a fine resolution $(1 \mathrm{~km})$ sufficient for the complex topography of the Alps, which resulted in more than 32000 simulation grid cells. To this aim, we applied the recently developed method GAPPARD (approximating GAP model results with a Probabilistic Approach to account for stand Replacing Disturbances) (Scherstjanoi et al., 2013) to LPJ-GUESS. GAPPARD derives mean output values from a combination of simulation runs without disturbances and a patch age distribution defined by the disturbance frequency. With this computationally efficient method, which increased the model's speed by approximately the factor 8 , we were able to faster detect the shortcomings of LPJ-GUESS functions and parameters. We used the adapted LPJ-GUESS together with GAPPARD to assess the influence of one climate change scenario on dynamics of tree species composition and biomass throughout the 21st century in Switzerland. To allow for comparison with the original model, we additionally simulated forest dynamics along a north-south transect through Switzerland. The results from this transect confirmed the high value of the GAPPARD method despite some limitations towards extreme climatic events. It allowed for the first time to obtain area-wide, detailed high-resolution
\end{abstract}

LPJ-GUESS simulation results for a large part of the Alpine region.

\section{Introduction}

Climate change affects species composition, forest structure and biomass of forests worldwide. The appropriate modeling of forests at a large scale is important to assess their functions, in particular their influence on the global carbon cycle (Fischlin and Midgley, 2007; Purves and Pacala, 2008). This requires model functions that describe forest dynamics, particularly with respect to forest disturbances and structurerelated competition (Bonan, 2008; Quillet et al., 2010).

The well established dynamic global vegetation models (DGVMs) simulate dynamics of vegetation, including forests, based on main plant physiological functions. The first-generation DGVMs simulate the vegetation of one plant functional type (PFT) or species in a stand aggregated in one individual (big-leaf approach). Therefore, they do not take into account forest structure and show limitations in modeling competition and disturbances (Quillet et al., 2010), which might especially affect mixed forests and the vegetation growth under dry conditions (Smith et al., 2001). Second-generation DGVMs (Sato et al., 2007; Hickler et al., 2008; Fisher et al., 2010), also termed hybrid models, account for structural characteristics, improve the modeling of competition and small-scale disturbances, and thus lead to more realistic simulations of forest dynamics, but on the cost of either model resolution, model extent or simulation speed. 
One commonly used but simulation time-consuming way to include structural characteristics into a DGVM is the gap approach (Botkin et al., 1972; Shugart, 1984), which stochastically simulates dynamics of tree individuals or cohorts on numerous small patches, so that the mean of all stochastic replicates builds the result of one simulation step. The second-generation DGVM LPJ-GUESS (LundPotsdam-Jena General Ecosystem Simulator) (Smith et al., 2001; Hickler et al., 2004) combines such an approach with plant physiological functions of the LPJ-DGVM (Sitch et al., 2003). As it uses the gap approach, LPJ-GUESS is yet not computationally efficient enough to simulate forests with a fine resolution $(<1 \mathrm{~km})$ on a large scale (continental to global). Area-wide simulations with LPJ-GUESS typically use resolutions of 10 or 50 arcmin (Gritti et al., 2006; Koca et al., 2006; Morales et al., 2007; Wolf et al., 2008; Hickler et al., 2012) to perform simulations on subcontinental to continental scales. To more specifically analyze model functions of LPJ-GUESS some studies focused on simulations on certain stands (e.g., for Switzerland Portner et al., 2010; Manusch et al., 2012; Wolf et al., 2012). However, the most recent LPJ-GUESS parameterization led to substantial discrepancies at a finer scale between model results and comparable data (Hickler et al., 2012).

We aimed to perform simulations with a $1 \mathrm{~km}$ resolution over the whole of Switzerland. Our decision to use Switzerland as a study area was supported by two main arguments: first, this specific region combines altitudinal gradients with a very rugged topography and different degrees of continentality and consequently contains different climate and vegetation zones. Therefore, it is a difficult test for every modeling exercise. Partly due to that, there are no dynamic area-covering climate change impact simulation studies on Swiss forests. Second, comparatively detailed climate and soil input data are available that are necessary for our modeling purposes. Despite the limitations at a finer scale, we chose to use LPJ-GUESS for the modeling because it contains detailed plant physiological functions combined with a structured vegetation and dynamics. However, recent results from Scherstjanoi et al. (2013) allow us to estimate that using a $1 \mathrm{~km}$ resolution over the whole of Switzerland would require several months of simulation time. To enable simulations over a large range we used a method that was lately developed by Scherstjanoi et al. (2013). With it, GAP model results are approximated with a Probabilistic Approach to account for stand Replacing Disturbances (GAPPARD method).

The GAPPARD method utilizes a modified version of the von Foerster equation of age-structured population dynamics (von Foerster, 1959). Several other approaches also used von Foerster types to approximate gap dynamics (Kohyama, 1993; Falster et al., 2010). Moorcroft et al. (2001), e.g., approximated in the second-generation DGVM ED (Ecosystem Demography Model) size and age by applying a van Foerster type equation. In contrast to GAPPARD, this size- and age-approximation method is applied during the simulations and for each simulation year. Hence, and also due to a lower spatial resolution in ED (Moorcroft et al., 2001), GAPPARD has most likely a higher computational efficiency. However, this increase in efficiency comes along at the cost of less precision on smaller timescales.

The approximation used by the method shortens LPJGUESS simulations (100 stochastic replicates) by roughly a factor of 10 . Therefore, the computationally efficient simulations were highly advantageous and enabled us to more rapidly analyze functions of the model and more easily adapt model parameters. This is the first time that this method is used area-wide on a large scale. Hence, our first aim was to test the applicability of the GAPPARD method. As we tested LPJ-GUESS on a finer scale than typically used and applied the model to a specific region, we expected that we will have to change model parameters and adapt model functions. It was, thus, our second aim to control how applicable the latest LPJ-GUESS parameters are to model the potential natural vegetation (PNV) in a heterogeneous Alpine landscape and on a finer scale, and what changes have to be made due to model functions and parameters to improve results. Our third aim was to use GAPPARD with the adjusted functions and parameters, and to assess (a) the usefulness of our modifications and (b) the potential influence of one climate change scenario on the development of forest biomass and species composition allover Switzerland. One main issue was the response of the different tree species to warmer and drier climates and to the increase in atmospheric $\mathrm{CO}_{2}$. Additionally, we were also interested in how the results of the adjusted LPJ-GUESS differ from the results using the most recent LPJ-GUESS functions and parameters (Hickler et al., 2012).

To sum up, our main research questions are the following.

- How applicable for area-wide studies over the whole of Switzerland is the GAPPARD method?

- How valuable are the recent LPJ-GUESS parameters and functions to model the potential natural vegetation in a heterogeneous Alpine landscape, and how do model functions and parameters have to be adapted to improve results?

- Which changes of forest biomass and species composition are projected by simulations over the whole of Switzerland using one climate change scenario and what trends do different parameters and input data indicate?

\section{Material and methods}

\subsection{LPJ-GUESS}

LPJ-GUESS is a process-oriented second-generation DGVM that simulates the vegetation dynamics of forests (Smith 
et al., 2001; Hickler et al., 2004). It shows characteristics from the first-generation DGVM LPJ (Sitch et al., 2003) and the individual-based (cohort-based) gap model GUESS (Smith et al., 2001). Plant physiological and biogeochemical processes are based on the formulations in the LPJ-DGVM. Plants are either simulated as tree species (Koca et al., 2006; Hickler et al., 2012) or aggregated to PFTs.

LPJ-GUESS uses a gap approach to simulate the fate of individual trees, determined by growth, stochastic establishment and stochastic death processes. Other stochastic elements can be climatic drivers and in particular stochastically appearing small-scale stand-replacing disturbances (disturbance stochasticity). Due to the stochasticity, individuals and vegetation biomass on each patch develop differently and simulations of many patches have to be averaged to yield the forest dynamics, requiring a lot of computational time. For gap models in general, Bugmann et al. (1996) recommended the use of 200 stochastic replicates per stand. In LPJ-GUESS, most commonly 50 or 100 of such replicates are used (as in Koca et al., 2006; Hickler et al., 2008, 2009; Miller et al., 2008; and Wramneby et al., 2008), but to save computational time the number of patches is often even smaller (e.g., 20 in Hickler et al., 2012).

\subsection{GAPPARD method}

The GAPPARD method (Scherstjanoi et al., 2013) is based on the idea that a forest does not necessarily have to be represented by different stochastic replicates but can be calculated with just one undisturbed simulation, which would be much more computationally efficient. The method assumes that stochastically appearing small-scale disturbance events that transfer all living biomass of a stochastic replicate to the litter are mainly responsible for the difference between a stochastic and a deterministic model run. In LPJGUESS such stand-replacing disturbances occur with a constant probability $p_{\text {dist }}$. The GAPPARD method furthermore assumes that the succession after a disturbance event is always the same, given a constant climate. Thus, values of state variables $y$ starting from bare patch produced for each simulation year $a$ in an undisturbed model run and information on the patch age distribution based on $p_{\text {dist }}$ can be used to approximate stochastic model run results. The expectation value $Y(T)$ of $y$, which includes the effect of small-scale disturbances, is calculated for each year $T$ in a postprocessing way:

$$
\begin{aligned}
Y(T) & =\left(1-p_{\text {dist }}\right)^{T} y(T) \\
& +p_{\text {dist }} \sum_{a=1}^{T-1}\left(1-p_{\text {dist }}\right)^{a} y(a) .
\end{aligned}
$$

The results of Scherstjanoi et al. (2013) showed that the other stochastic functions of LPJ-GUESS, establishment and mortality, either do not have a significant influence or their effect is included in the GAPPARD method. Therefore, an undisturbed model run is fully deterministic.

Using just one deterministic undisturbed run leads to an extrapolation of the vegetation succession pattern from the beginning of the simulations to the whole simulation period without considering the effect of changing drivers (in LPJGUESS changing climate). As a solution, additional deterministic undisturbed simulation runs starting from different points in time (nodes) are performed. The final result is interpolated between these nodes. A more detailed explanation of the derivation of the method is given in Scherstjanoi et al. (2013). For our study, we used five deterministic undisturbed simulations: one starting in 1100 with a spinup up to 1900 , one starting in 1950 , one in 2000 , one in 2050 , and one in 2080. After several tests (results not shown), and due to the results of Scherstjanoi et al. (2013) we decided to use a disturbance frequency of 0.0154 , corresponding to a return interval of 65 years.

Applying the GAPPARD method does not currently allow any spatial interactions between neighboring grid cells or patch-to-patch interactions. Therefore, seed dispersal or migration functions or the spatial mass effect of LPJ-GUESS (establishment in a patch depends on other patches' biomass in a stand) cannot be applied.

\subsection{Simulation setup}

We simulated forest dynamics on all cells of a $1 \mathrm{~km}$ grid of Switzerland where, at the moment, forests potentially could grow. Based on the Swiss soil suitability map (Frei, 1976), we excluded rocky, urban or water areas, which led to a simulation setup containing 32214 cells.

We applied climate change after the simulation year 1900. Up to 1900 we used randomly selected values of the first 30 climate data years for the model spinup. For the 19011929 simulation period, we used CRU (Climate Research Unit) data downscaled to the $1 \mathrm{~km}$ model grid (Mitchell et al., 2004). For the 1930-2006 simulation period, we used Swiss weather station data from the Federal Office of Meteorology and Climatology MeteoSwiss interpolated to a $100 \mathrm{~m}$ grid by applying the Daymet method (Thornton et al., 1997). For the 2007-2100 simulation period, we used CRU climate data of one A1B climate scenario (Mitchell et al., 2004). Along with that scenario we used $\mathrm{CO}_{2}$ data that reach 703 ppm (parts per million) in 2100 (IPCC, 2001, Annex II). To be able to make statements about the $\mathrm{CO}_{2}$ effect, we additionally performed simulations with constant atmospheric $\mathrm{CO}_{2}$ from the simulation year $2000 \mathrm{on}$. A visualization of the climate used for the simulations is given in Fig. D2 (Appendix).

We developed and applied an empirical model to estimate daily cloud coverage of each simulated stand. It uses available climate data from 59 Swiss weather stations (Table D1 in the Appendix) to predict cloud coverage from season, and precipitation and altitude of a stand. A more detailed description is given in Appendix $\mathrm{C} 1$. 
Based on the Soil Suitability Map of Switzerland (Frei, 1976), we defined the required LPJ-GUESS soil parameters: usable volumetric soil water holding capacity (fraction of soil layer depth), soil thermal diffusivities at different points of water holding capacity and an empirical parameter for the percolation equation. A more detailed description is given in Appendix C2.

\subsection{Model adaptation}

We applied two parameter sets to our simulations, one with existing parameters and one with new ones (see Table D10 in the Appendix). For simulations with the first parameter set we used all boreal and temperate species Hickler et al. (2012) used for their simulations, as well as C3 grass and boreal evergreen shrubs. We applied the species parameters of Hickler et al. (2012) who simulated the PNV across Europe. For boreal evergreen shrubs we additionally used parameters of Wolf et al. (2008). Here we refer to this set as the standard parameter set. Considering that LPJGUESS was not designed for this specific region and a fine scale and based on first tests (results not shown), we expected from the results that (1) the species distribution would differ from PNV, (2) not all important tree species would be modeled, and (3) the occurrence of some species might end too abruptly.

We created a second parameter set to improve simulations of the PNV in Alpine landscapes. For this aim, we used general knowledge and different publications on PNV (Ellenberg, 1986; Brzeziecki et al., 1993; Bohn et al., 2004; Frehner et al., 2005). We did not use stand data to fine-tune LPJ-GUESS because almost all Swiss forests have been influenced by forest management for a long period. To this set, to which we will refer to as the adjusted parameter set, we additionally added the three new species Larix decidua, Pinus cembra and Pinus mugo as described in Scherstjanoi et al. (2013). The fine-tuning of LPJ-GUESS includes a new function to describe the leaf senescence of Larix decidua. Its photosynthetic activity decreases in fall with an s-shaped curve (based on results of Migliavacca et al. (2008), see Appendix A). Furthermore, we developed a modified functionality of the plant parameter of the maximum 20-year coldest month mean temperature for establishment. This parameter is a proxy for chilling requirements for seed germination; if the 20-year coldest month mean temperature exceeds the parameter's value, establishment of boreal species is prevented (Nienstaedt, 1967, as cited in Prentice et al., 1992). Instead of allowing no establishment above this limit, we used a function that decreases the amount of new saplings with an sshaped curve. This novelty allows shade tolerant boreal trees to also grow in more temperate vegetation zones but not to such a degree that they dominate the forests (see Appendix A for details). Based on Scherstjanoi et al. (2013), we changed further parameters mainly addressing drought resistance and temperature dependencies.

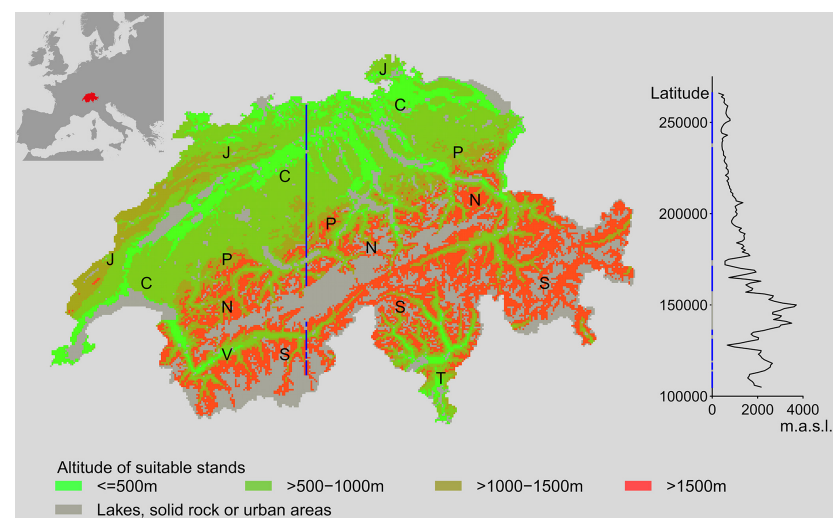

Figure 1. Location of and altitude along the analyzed transect, and location of geographic terms. The transect (blue line) is placed at a longitude of $638000 \mathrm{~m}$ (Swiss CH1903/lv03 coordinates). J: Jura; C: Central Plateau; P: Prealps; N: north Alps; S: south Alps; V: Valais; T: Ticino.

\subsection{Simulation evaluation}

For both applied parameter sets, we mapped total biomass, the biomass of all single main species for the year 2000, and the biomass differences between 2000 and 2100. Additionally to the Switzerland-wide simulations, we mapped the temporal course of the biomass of the main species along an exemplary north-south transect (Fig. 1) to (1) get a more detailed idea of the temporal development of the species composition and species biomass, and (2) have a smaller amount of grid cells so that results can be compared to stochastic LPJ-GUESS simulations using 100 stochastic replicates. The transect covers the east Jura, the Central Plateau, the central Prealps, the northwest Alps, and the Valais. Along this transect we displayed the changes in biomass between 1900 and 2100. For the comparison along the transect, we mapped the biomass change of the species along time for both, LPJGUESS results and GAPPARD results. To quantify the quality of the GAPPARD-approximated results we calculated a root mean square error (RMSE) between the stochastic LPJGUESS results and the GAPPARD results for each stand of the transect and each species. Here, we present the mean RMSE value of all stands of the transect. The RMSE corresponds to the differences in carbon mass between the two models in each simulation year (described in detail in Appendix B). For every species, each of these differences enter into the calculation of the RMSE as a fraction of the maximum possible difference appearing in that stand and the calculated simulation period. Hence, the maximum RMSE is one (completely different results). We calculated the RMSEs only for the climate change period. Furthermore, we compared the simulation time between both simulation types. The simulations ran on one core of an AMD Opteron 2439 $2.8 \mathrm{GHz}$ processor. 
Table 1. Root Mean Square Error of the carbon mass between LPJGUESS results and GAPPARD results along the mapped transect. LPJ-GUESS used 100 stochastic replicates. Values were calculated as a mean of all simulated stands in between 1901 and 2100.

\begin{tabular}{lc}
\hline & Root mean square error \\
\hline Boreal evergreen shrubs & 0.27 \\
Betula pubescens & 0.24 \\
Larix decidua & 0.2 \\
Picea abies & 0.27 \\
Pinus cembra & 0.27 \\
Pinus mugo & 0.22 \\
Pinus sylvestris & 0.19 \\
Abies alba & 0.25 \\
Betula pendula & 0.12 \\
Carpinus betulus & 0.13 \\
Corylus avellana & 0.14 \\
Fagus sylvatica & 0.15 \\
Fraxinus excelsior & 0.15 \\
Quercus pubescens & 0.12 \\
Quercus robur & 0.13 \\
Tilia cordata & 0.13 \\
Total carbon mass & 0.08 \\
\hline
\end{tabular}

The terms describing geographical regions mentioned in the following sections are defined in Fig. 1. Here, we describe the biomass as in kilograms per square meter $\left(\mathrm{kg} \mathrm{m}^{-2}\right)$, consistent with the LPJ-GUESS output variable. Assuming that carbon makes half of the wood's total mass and a wood density of $0.5 \mathrm{~g} \mathrm{~cm}^{-3}, 1 \mathrm{kgC} \mathrm{m}^{-2}$ equals $40 \mathrm{~m}^{3}$ wood ha ${ }^{-1}$ or $20 \mathrm{t} \mathrm{biomass} \mathrm{ha}^{-1}$.

\section{Results}

\subsection{Simulations along the transect}

Applying the GAPPARD method generally decreased the simulation time. Simulations along the transect with LPJGUESS required $27 \mathrm{~h} 58 \mathrm{~min}$, and thus about the 8 -fold computing time as those with the GAPPARD method: $3 \mathrm{~h} 28 \mathrm{~min}$ (all values are a mean of 10 simulations). The results along the transect for both methods in general were similar (Figs. 2, 3 , for the location of regions refer to Fig. 1). The RMSE for the total carbon mass between both used methods was smaller than 0.1. The RMSE for single species was always smaller than 0.3, for most species smaller than 0.2 (Table 1). Generally the GAPPARD results appear more smoothed, along the latitudinal axis as well as in time. LPJ-GUESS, on the other hand, tends to show irregularities and stripelike patterns. Within a few years particularly the biomass of broadleaved species can decrease or increase suddenly and over large sections of the transect. However, this is the only remarkable difference between the methods.

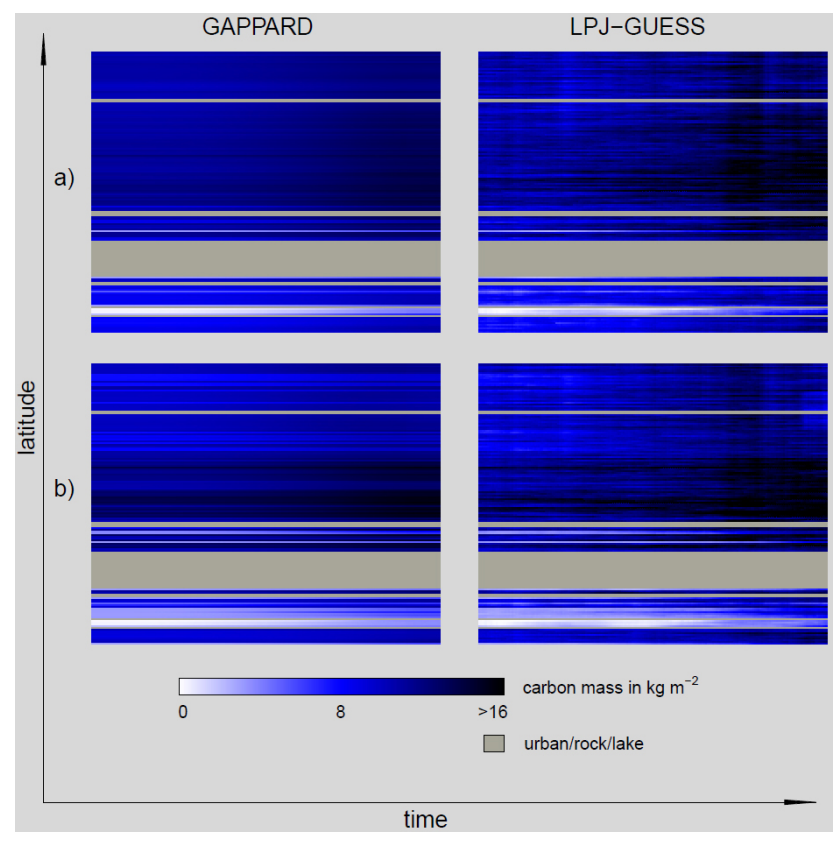

Figure 2. Total carbon mass development along the analyzed transect from 1900 (left side) to 2100 (right side) with LPJ-GUESS (100 stochastic replicates) and using the GAPPARD method. (a) adjusted parameter set; (b) standard parameter set.

Both methods used show a biomass increase of drought resistant species (e.g., Quercus pubescens and Pinus sylvestris), a shift or area extension of most species to higher altitudes, and a general increase in biomass over time. In the transect, the shift of species to higher stands can most clearly be seen in some higher elevated parts of the Valais region, where at the beginning of the 21 st century no trees at all appeared whereas at the end of the century a high biomass of Larix decidua and Pinus cembra occurred.

\subsection{Switzerland-wide simulations for 2000}

Applying the standard parameter set, in the year 2000 the carbon mass of most stands' forests was between 9 and $13 \mathrm{kgC} \mathrm{m}^{-2}$ (Fig. 4a, for the region names cf. Fig. 1, Table 2). In particular, the carbon mass was lowest above the upper treeline and in the dry inner Alpine valleys $\left(<4 \mathrm{kgC} \mathrm{m}^{-2}\right)$, and highest in stands of the Jura, the Ticino and the Prealps $\left(>14 \mathrm{kgC} \mathrm{m}^{-2}\right)$. Using the adjusted parameter set, we simulated a similar total biomass as with the standard LPJGUESS parameter set, with a few exceptions (Fig. 4a). The biomass in higher stands of the Jura and the Prealps was slightly smaller and in the Central Plateau slightly higher. Additionally, the increase in biomass from the lowest stands of the Central Plateau to stands in the Prealps was smoother. 
Table 2. Total simulated (rough values) and actual biomass for the years 2000 and 2100. CP: Central Plateau; JA: Jura; PA: Prealps; NA: Central, northwest and northeast Alps; SA: south, southeast and southwest Alps (see Brändli (2009) for the detailed locations of regions); SP: standard parameter set; AP: adjusted parameter set; APS: Forest stock approximated from AP 2000 results $\left(10 \mathrm{kgC} \mathrm{m}^{-2}\right.$ are equivalent to $400 \mathrm{~m}^{3}$ wood ha ${ }^{-1}$; see Sect. 2.5); NFIS: actual forest stock as result of the newest SWISS national forest inventory (Brändli, 2009). Units of SP and AP are in kilograms of carbon per square meter $\left(\mathrm{kgC} \mathrm{m}^{-2}\right)$. Units of APS and NFIS are in cubic meters of wood per hectare $\left(\mathrm{m}^{3}\right.$ wood $\left.\mathrm{ha}^{-1}\right)$.

\begin{tabular}{lllllll}
\hline & AP 2000 & AP 2100 & SP 2000 & SP 2100 & APS 2000 & NFIS \\
\hline CP & 10 & 12 & 9 & $10-11$ & 400 & $387-411$ \\
JA & $11-12$ & $12-13$ & $9-13$ & $12-15$ & $440-480$ & $367-369$ \\
PA & $11-12$ & $12-15$ & $9-13$ & $12-16$ & $440-480$ & $416-466$ \\
NA & $9-11$ & $11-12$ & $9-12$ & $10-12$ & $360-440$ & $329-358$ \\
SA & $7-11$ & $7-12$ & $7-11$ & $7-12$ & $280-440$ & $225-298$ \\
\hline
\end{tabular}

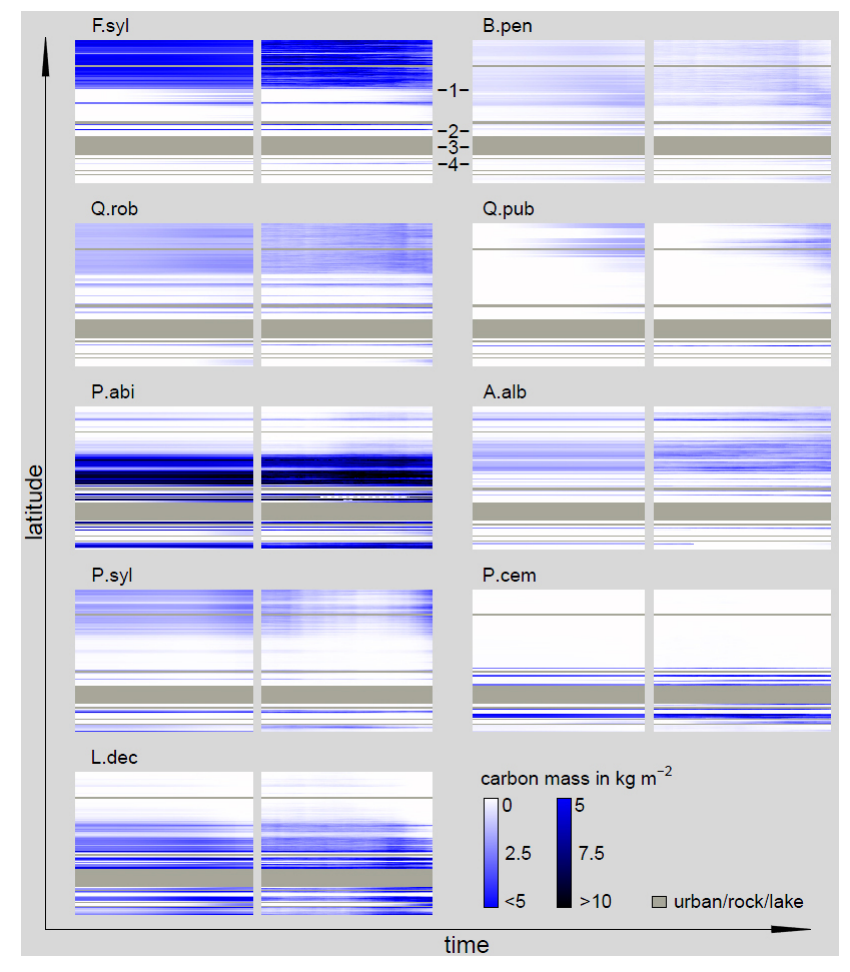

Figure 3. Carbon mass development along the analyzed transect of nine selected species using the stochastic (100 replicates) LPJGUESS approach (right) and the GAPPARD method (left), both with the adjusted parameter set. The timescale on each plot extends from 1900 (left side) to 2100 (right side). A.alb: Abies alba; B.pen: Betula pendula; F.syl: Fagus sylvatica; L.dec: Larix decidua; P.abi: Picea abies; P.cem: Pinus cembra; P.syl: Pinus sylvestris; Q.pub: Quercus pubescens; Q.rob: Quercus robur; 1: Central Plateau; 2: north Alps; 3: main Alpine ridge; 4: Valais. For the location of regions see Fig. 1.

\subsubsection{Simulations of single species for the year 2000 with the standard parameter set}

Applying the standard parameter set, at the end of the 20th century either Picea abies or Fagus sylvatica dominated

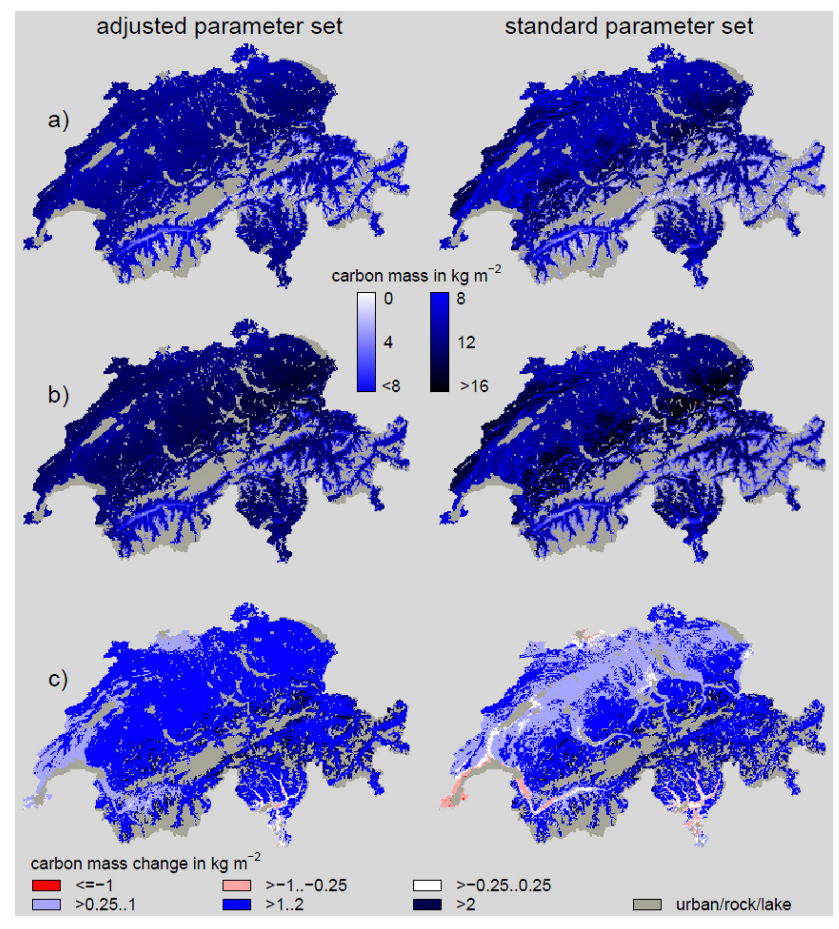

Figure 4. Total carbon mass simulated with the adjusted and the standard parameter set, both using GAPPARD, for (a) 2000 and (b) 2100. Total carbon mass changes between (a) and (b) are displayed in (c).

most stands (Fig. 5, for the region names cf. Fig. 1, Table 3). Fagus sylvatica grew in stands below approximately $600 \mathrm{~m}$, and was very dominant on humid sites. Up to roughly $1000 \mathrm{~m}$ it co-occurred with Pinus sylvestris or Picea abies as a secondary species. Betula pendula hardly established. Most broadleaved summer-green species reached their highest biomass values in the Central Plateau, in the dry inner Alpine valleys and valleys of the Jura. Quercus pubescens was a dominant species in southwest Switzerland, and in the valley bottoms of the Ticino and the Valais, where $\mathrm{Fa}$ gus sylvatica was less dominant. As a minor species it also 


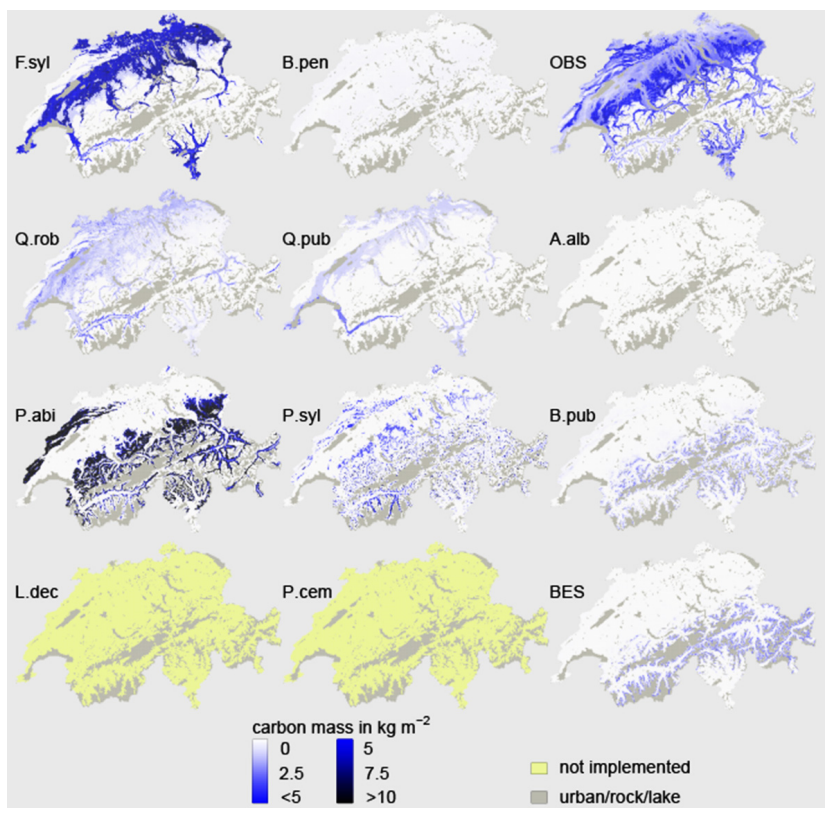

Figure 5. Carbon mass simulated with the standard parameter set for single species at 2000. A.alb: Abies alba; B.pen: Betula pendula; B. pub: Betula pubescens; F.syl: Fagus sylvatica; L.dec: Larix decidua; P.abi: Picea abies; P.cem: Pinus cembra; P.syl: Pinus sylvestris; Q.pub: Quercus pubescens; Q.rob: Quercus robur; BES: boreal evergreen shrubs; OBS: other broadleaved species (Carpinus betulus, Corylus avellana, Fraxinus excelsior and Tilia cordata).

appeared in the lowest stands of the Central Plateau. Abies alba was modeled, but did not establish at all. The occurrence of Picea abies was generally restricted to stands at altitudes higher than approximately $1000 \mathrm{~m}$. Its dominance reached up almost to the highest potential inhabitable stands in the Alps, but a small stripe above remained where it did not establish. Pinus sylvestris occurred only above approximately $600 \mathrm{~m}$, but only established on stands below Picea abies or besides Betula pubescens at the upper treeline.

\subsubsection{Simulations of single species for the year 2000 with the adjusted parameter set}

Applying the adjusted parameter set generally allowed more species to co-occur and the dominance of species was less pronounced (Fig. 6, for the region names cf. Fig. 1, Table 3). In contrast to the standard parameter set, Pinus sylvestris grew in the lower Central Plateau stands and valley bottoms of the Valais and Ticino, and was most successful on drier stands. Generally, a mixed forest that was dominated by $\mathrm{Fa}$ gus sylvatica developed in the Central Plateau, with Quercus robur besides Pinus sylvestris as the main secondary species. Betula pendula established as well on most stands below approximately $1000 \mathrm{~m}$ but on the very dry ones, and became more successful with increasing altitude and fewer Fagus sylvatica biomass. Also, Quercus pubescens established in

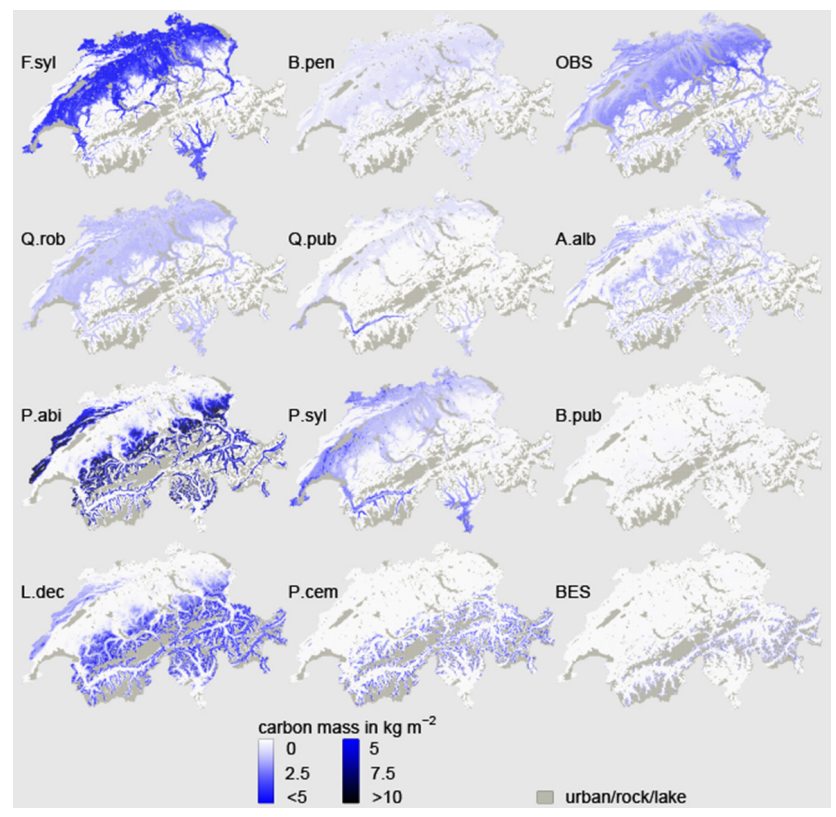

Figure 6. Carbon mass simulated with the adjusted parameter set for single species at 2000. See Fig. 5 for species abbreviations.

small densities at the lowest elevation sites of the Central Plateau; it was more successful in the southwest and especially in the Valais, similarly to the standard set. All the species that grew in the Central Plateau also established in the low Alpine valleys, but Fagus sylvatica and Betula pendula did not grow there on drier sites. Abies alba established, in contrast to the standard parameter set simulations. It appeared in the transition zone between the Central Plateau and higher altitudes, and there co-occurred with Central Plateau species or Picea abies. It did not grow in the lower parts of the Central Plateau, but increased its biomass stepwise from approximately $600 \mathrm{~m}$ on and decreased again at approximately $1200 \mathrm{~m}$. Picea abies was less dominant in the Jura and the Prealps than with the standard parameter set. Similarly to Abies alba, the biomass of Picea abies decreased gradually to zero from mountainous stands down to higher sites of the Central Plateau. Two of the three newly parameterized species appeared as main species: Larix decidua with gradually increasing biomass from the lower montane vegetation zone up to the subalpine zone and Pinus cembra restricted to the subalpine zone.

\subsection{Development of GAPPARD simulations until the year 2100 focusing on the adjusted parameter set}

The temporal course of the climate change simulations with the GAPPARD method and the adjusted parameter set was rather smooth (Fig. 2a, left). The biomass increased in all except a few stands in the valley bottoms of the Ticino and the Valais, where it decreased by up to $0.5 \mathrm{kgC} \mathrm{m}^{-2}$ (Fig. $4 \mathrm{~b}, \mathrm{c}$, left). For most parts of Switzerland, we simulated an increase 
Table 3. Simulation results of selected species for the different regions. Units in $\mathrm{kgC} \mathrm{m}^{-2}$. I: standard parameter set results for 2000 ; II: adjusted parameter set results for 2000; III: development of standard parameter set results until 2100; IV: development of adjusted parameter set results until 2100; a: Central Plateau and low sites in the Ticino; b: Alpine valley bottoms (submontane/colline); c: lower montane vegetation zone of Jura, Prealps and Alps; d: upper montane vegetation zone; e: subalpine vegetation zones; n.i.: not implemented; -: species did not establish or only had a very small biomass; N: none if too dry; *: strongly increases with water availability; **: strongly decreases with water availability; U: on upper stands; L: on lower stands; D: on dry sites; T: only Ticino; SA: south Alps; $\Uparrow:$ increase higher than $3 \mathrm{kgC} \mathrm{m}^{-2}$; $\uparrow:$ increase of $1-2 \mathrm{kgC} \mathrm{m}^{-2} ; \nearrow$ : increase lower than $1 \mathrm{kgC} \mathrm{m}^{-2} ; \rightarrow$ : roughly constant; \: decrease lower than $1 \mathrm{kgC} \mathrm{m}^{-2} ; \downarrow$ : decrease of $1-2 \mathrm{kgC} \mathrm{m}^{-2} ; \rightsquigarrow$ : varies strongly; see Fig. 5 for species abbreviations.

\begin{tabular}{|c|c|c|c|c|c|c|c|c|c|c|c|c|}
\hline & & F.syl & B.pen & Q.rob & Q.pub & P.syl & A.alb & P.abi & B.pub & BES & L.dec & P.cem \\
\hline \multirow[t]{5}{*}{ I } & $\mathrm{a}$ & $6 . .9^{\mathrm{L}}, 2^{\mathrm{U}}$ & $<0 . .2$ & $0 . .4$ & 2 & $>4 . .5^{\mathrm{U}}$ & - & - & - & - & n.i. & n.i. \\
\hline & $\mathrm{b}$ & $0 . .6^{*}$ & $<0 . .2$ & $0 . .6$ & $>0 . .5^{* *}$ & - & - & - & - & - & n.i. & n.i. \\
\hline & c & - & - & - & - & - & - & $5 . .>10$ & $<1^{*}$ & - & n.i. & n.i. \\
\hline & d & - & - & - & - & $0-10$ & - & $1 . .>10^{*}$ & $0 . .5^{*}$ & - & n.i. & n.i. \\
\hline & $\mathrm{e}$ & - & - & - & - & - & - & - & $0 . .5^{*}$ & $1 . .4$ & n.i. & n.i. \\
\hline \multirow[t]{5}{*}{ II } & $\mathrm{a}$ & $4 . .6$ & $0 . .3^{*}$ & 2 & $0 .$. & $>0 . .5^{* *}$ & $2 . .3^{\mathrm{U}}$ & - & - & - & - & - \\
\hline & $\mathrm{b}$ & $5^{\mathrm{N}}$ & $0 . .1^{*}$ & 2 & $1 . .5^{* *}$ & $>0 . .6^{* *}$ & $2^{\mathrm{U}}$ & - & - & - & - & - \\
\hline & $\mathrm{c}$ & - & - & - & - & - & 2 & $>0 . .10$ & $<0.5^{*}$ & - & $2 . .3$ & - \\
\hline & d & - & - & - & - & - & - & $5 . .10$ & $<0.5^{*}$ & - & $4 . .6$ & - \\
\hline & $\mathrm{e}$ & - & - & - & - & - & - & - & $<0.5^{*}$ & $1.4^{\mathrm{U}}$ & $4 . .6$ & 5 \\
\hline \multirow[t]{5}{*}{ III } & $\mathrm{a}$ & $\mathrm{L}_{\Uparrow} \mathrm{U}$ & $\rightarrow$ & & $\Uparrow^{L_{\uparrow} U}$ & $\mathrm{~V}^{\mathrm{U}}$ & - & - & - & - & n.i. & n.i. \\
\hline & $\mathrm{b}$ & $\mathrm{L}_{\Uparrow} \mathrm{U}$ & $\rightarrow$ & $\searrow$ & $\rightarrow$ & $\searrow^{4}$ & - & - & - & - & n.i. & n.i. \\
\hline & $\mathrm{c}$ & $\nearrow^{\mathrm{L}}$ & $\rightarrow$ & $\mathrm{N}$ & - & $\rightsquigarrow$ & - & $\searrow$ & $\rightarrow$ & - & n.i. & n.i. \\
\hline & d & - & $\nearrow^{\mathrm{L}}$ & $\pi \mathrm{SA}$ & - & $\rightsquigarrow$ & - & $\Uparrow$ & $\searrow$ & - & n.i. & n.i. \\
\hline & $\mathrm{e}$ & - & - & - & - & - & - & $\uparrow$ & $\vec{\nearrow}$ & $\searrow^{\mathrm{L}} \nearrow^{\mathrm{U}}$ & n.i. & n.i. \\
\hline \multirow[t]{5}{*}{ IV } & a & $\searrow^{L}$ & $\searrow^{\mathrm{T}, \mathrm{D}}$ & $D$ & $\uparrow^{\mathrm{L}} \nearrow$ & $\uparrow^{\mathrm{L}} \nearrow^{\mathrm{U}}$ & $\rightarrow$ & - & - & - & - & - \\
\hline & b & $\rightarrow$ & $\rightarrow$ & ${ }^{D} \nearrow^{\mathrm{U}}$ & $\nearrow$ & $\nearrow^{\mathrm{L}} \searrow^{\mathrm{U}}$ & $\rightarrow$ & - & - & - & - & - \\
\hline & $\mathrm{c}$ & $\nearrow^{\mathrm{L}}$ & $\nearrow$ & $\nearrow$ & - & - & $\rightarrow$ & $\searrow$ & $\rightarrow$ & - & $\searrow$ & - \\
\hline & d & - & $\nearrow$ & - & - & - & - & $\uparrow$ & $\rightarrow$ & - & $\rightarrow$ & - \\
\hline & $\mathrm{e}$ & - & - & - & - & - & - & $\Uparrow^{\mathrm{L}}$ & $\nearrow$ & $\searrow^{\mathrm{L}} \nearrow^{\mathrm{U}}$ & $\Uparrow$ & $\searrow^{\mathrm{L}} \nearrow^{\mathrm{U}}$ \\
\hline
\end{tabular}

of $1-2 \mathrm{kgC} \mathrm{m}^{-2}$ (Table 2). The increase was highest at the upper treeline. In the east of the Jura, most lower stands of the Valais, and in the southwest of Switzerland the increase in carbon mass was lower than $1 \mathrm{kgC} \mathrm{m}^{-2}$. Using the standard parameter set yielded a very similar picture. One difference is that in the Central Plateau the increase was rather small $\left(<1 \mathrm{kgC} \mathrm{m}^{-2}\right)$. Another difference is that forest biomass decreased in lower parts east of the Jura, and in stands at the valley bottoms of the Ticino and the Valais (up to $1 \mathrm{kgC} \mathrm{m}^{-2}$ ).

The changes in biomass show that drought-adapted species benefited most from climate change, and that boreal species lost the most biomass in lower stands and experienced a gain of biomass in higher stands (Figs. 7, 8 left; Table 3; Fig. D3 in the Appendix). Climate change led to an increase of Pinus sylvestris biomass in most stands. On sites in southwest and north Switzerland, and on stands of the dry inner Alpine valleys, the increase was highest. Its biomass only decreased on mid-altitudinal sites in the Valais. The biomass of Fagus sylvatica increased on stands of the Jura and the Prealps and decreased in the lower part of the Central Plateau. Quercus robur biomass increased on most stands, but some low sites in the southwest. Quercus pubescens increased its biomass on most stands and, besides Pinus sylvestris, was the only species benefiting from climate change in the lower part of the Central Plateau. It was also the species with the highest increase in distribution area and it only lost biomass in some stands of the southwest. Picea abies biomass decreased in most parts of the Jura and the Prealps. In contrast, on most stands of the Alps and higher stands of the Prealps the biomass of Picea abies increased. Abies alba biomass did not change significantly. Besides Picea abies, the newly implemented species Larix decidua and Pinus cembra were most successful establishing at higher altitudes, specifically where they were not growing at the end of the 20th century. However, Larix decidua biomass decreased in the Jura and the Prealps, and Pinus cembra lost approximately a third of its biomass on lower sites and only increased on very high sites. Betula pendula benefited from the decrease in Larix decidua biomass in the Prealps and the Jura and increased its biomass there.

With the standard parameter set, simulations until 2100 for some species led to clearly different patterns (Fig. 8; Figs. D4-D6 in the Appendix); besides those species that were not parameterized for or were not able to establish well 


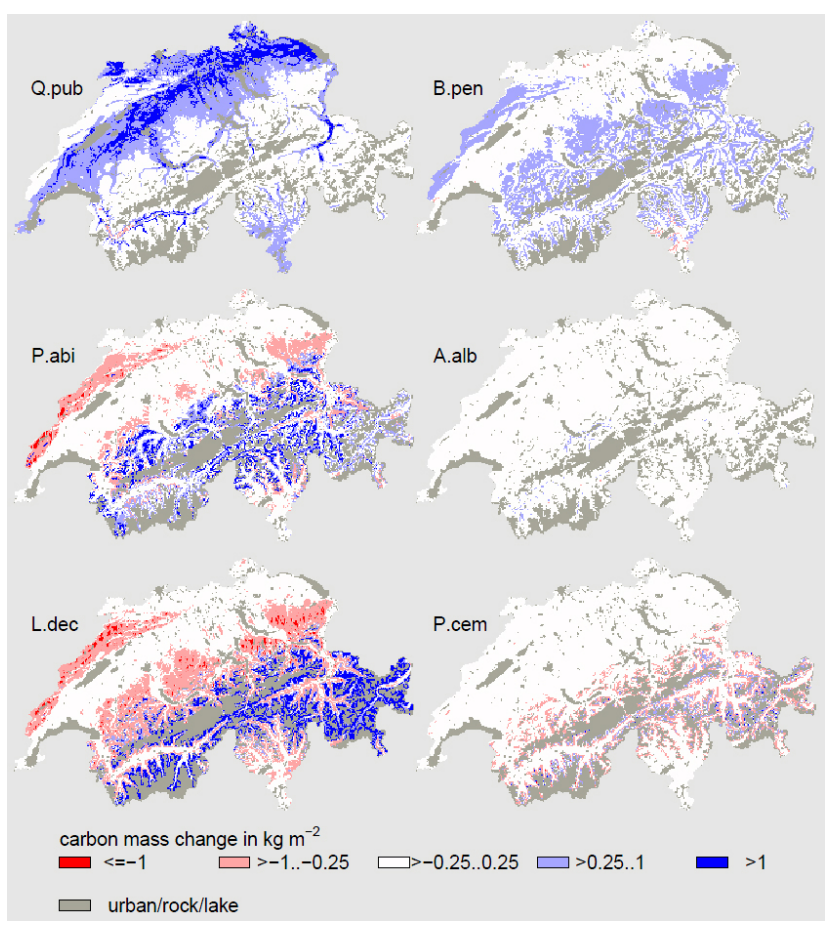

Figure 7. Changes in carbon mass between 2000 and 2100 for six selected species simulated with the adjusted parameter set. See Fig. 5 for species abbreviations.

with the standard set, this is mainly true for Pinus sylvestris, Fagus sylvatica and Quercus robur. In contrast to the adjusted set, Pinus sylvestris lost biomass on all but a few high elevation stands and mid-altitudinal stands of the Valais, $\mathrm{Fa}$ gus sylvatica increased its biomass largely in the higher elevations of the Central Plateau, and the biomass of Quercus robur decreased on most stands of the Central Plateau.

\subsection{Development under constant $\mathrm{CO}_{2}$ conditions}

Applying constant $\mathrm{CO}_{2}$ from 2000 on led to a decrease of total biomass on most stands (Fig. 9). The total carbon mass in the Central Plateau decreased by more than $2 \mathrm{kgC} \mathrm{m}^{-2}$. We simulated an increase of biomass only above approximately $1000 \mathrm{~m}$. The only species that still benefited from the temperature increase in the Central Plateau were Quercus pubescens and Pinus sylvestris.

\subsection{Summary of the most important changes by adjusting the parameters}

By using the adjusted parameter set we significantly changed simulation results of forest dynamics. The implementation of the three species Larix decidua, Pinus cembra and Pinus mиgo was one major change. The modeling of particularly Larix decidua and Pinus cembra and the adjustment of temperature- and drought-related parameters of species in general led to an altered species distribution in comparison to

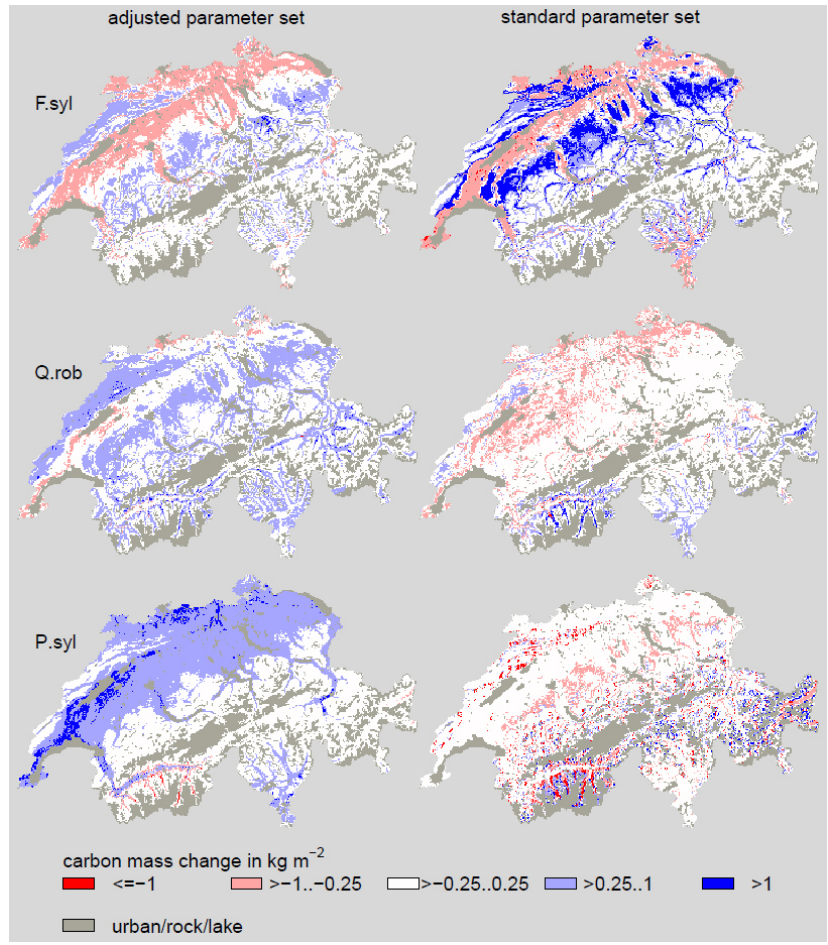

Figure 8. Changes in carbon mass between 2000 and 2100 for three selected species compared between simulations with the adjusted parameter set and the standard parameter set. See Fig. 5 for species abbreviations.

simulations with LPJ-GUESS standard parameters. Concerning LPJ-GUESS standard species, we replaced especially the regions where Pinus sylvestris and Abies alba occurred. Moreover, we reduced the dominance of Fagus sylvatica and Picea abies. Furthermore, we enabled more gradual transitions between species of different vegetation zones, in particular between Picea abies, Abies alba and species below the upper montane vegetation zone.

\section{Discussion}

\subsection{The GAPPARD method}

By applying the GAPPARD method we were able to simulate forest dynamics across Switzerland on a fine grid requiring a short simulation time. Hence, we were able to analyze the effects of the chosen climate change scenario on forest dynamics in the heterogeneous topography of Switzerland.

Our simulations along the transect once again confirmed that the GAPPARD method provides good approximations of the stochastic LPJ-GUESS, already shown for sample sites (Scherstjanoi et al., 2013). This is reflected in the RMSE values. Furthermore, the comparison of simulation times emphasizes the computational efficiency of GAPPARD. Using GAPPARD we were able to efficiently adjust a parameter 


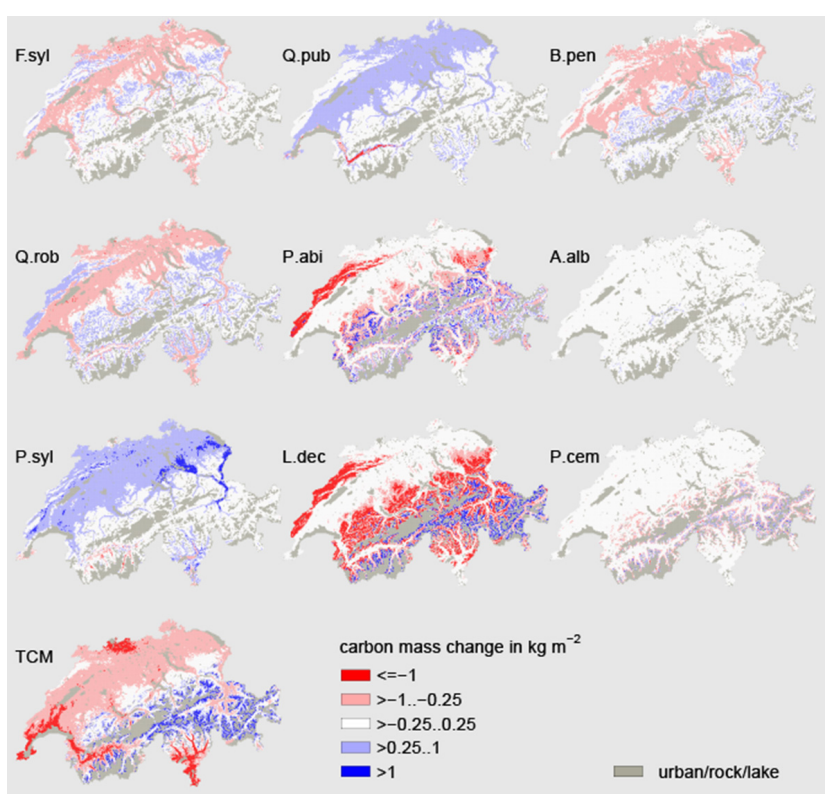

Figure 9. Changes in carbon mass between 2000 and 2100 simulated with the adjusted parameter set under a constant $\mathrm{CO}_{2}$ level from year 2000 on. See Fig. 5 for species abbreviations. TCM: total carbon mass change. Compare to Figs. 7 and 8 for single species results under a rising $\mathrm{CO}_{2}$ level, and to Fig. 4 for total carbon mass results under a rising $\mathrm{CO}_{2}$ level.

set and to improve functions of the complex forest model LPJ-GUESS. For the first time, simulations of LPJ-GUESS could be run over the whole of Switzerland and on all potentially suitable cells on a $1 \mathrm{~km}$ grid (more than 32000 grid cells). Hence, the method has the potential to be applied to other regions with a similar or larger number of grid cells. The usefulness of the GAPPARD method can be highlighted even more by extrapolating the simulation time the stochastic LPJ-GUESS required for the transect (131 grid cells) across all of Switzerland (assuming that the transect is representative for Switzerland). If ten processors are used in parallel the Switzerland-wide simulations would roughly last 30 days, which complicates an analysis of results, whereas with GAPPARD Switzerland-wide simulations required only 3-4 days.

By applying GAPPARD, we indirectly showed that the parameter of LPJ-GUESS with the strongest influence on the stochasticity of results is the return interval for standreplacing disturbances. The great influence of this parameter was already shown in other studies (Hickler et al., 2004; Gritti et al., 2006; Scherstjanoi et al., 2013). One great advantage of the GAPPARD method is that the results of the deterministic runs, starting from different nodes (see Sect. 2.2), can easily be used for multiple values of disturbance intervals. The main reason for this is that GAPPARD is applied in a postprocessing way, and requires substantially less computational time than the deterministic simulation runs (roughly
15 min for the whole of Switzerland). Thus, furthermore underlining the great potential of our method, disturbance intervals could also be easily implemented as stand specific (e.g., soil, management or altitude specific). However, in this study we did not focus on the analysis of disturbance frequency and chose one constant value for the disturbance interval. In contrast to the standard LPJ-GUESS value of 100 years we used an interval of 65 years. Our decision for a low disturbance return interval was mainly based on the idea to also consider the effects of other disturbances (e.g., wind, fire, parasites, human disturbances) and was also supported by recent results of Scherstjanoi et al. (2013).

The most remarkable difference in our results between the stochastic LPJ-GUESS simulations and the GAPPARD method concerns the intensity with which the biomass can change over time. Most likely, extreme climatic events, i.e., dry periods combined with high temperatures, led to extinction events when simulated with the stochastic LPJGUESS. In a similar way the vegetation increased as a response to good growing conditions. In contrast, applying the GAPPARD method on LPJ-GUESS led to smoothed results. On the one hand this is limiting the use of the GAPPARD method on shorter temporal scales. On the other hand, the long-term trends of both methods used were very similar, and the longer temporal scale applicability is not negatively influenced.

Still, there are some limitations. One shortcoming of the GAPPARD method is the current impossibility of allowing spatial interactions (see Sect. 2.2). Especially migration might have a significant influence on the change of species composition under a changing climate (Lischke, 2005; Neilson et al., 2005; Lischke et al., 2006; Epstein et al., 2007; Snell et al., 2014). The shift of species towards higher altitudes simulated here was not constrained by tree dispersal. Whenever climatic conditions allowed, tree species grew there. Therefore, the simulated shifts might be too fast and the species composition could be biased. However, this limitation also addresses LPJ-GUESS as it does not include a migration function. Furthermore, the role of demographic stochasticity (stochastic establishment and mortality) has not been fully covered by the GAPPARD method, as we assume that small-scale disturbances have the biggest potential to achieve deviations from the deterministic LPJ-GUESS run. When applying the method to other models it should be first tested how much influence a demographic stochasticity has.

\subsection{Switzerland-wide simulations}

We evaluated the plausibility of our results by comparing them with the assumed PNV (Ellenberg, 1986; Brzeziecki et al., 1993; Bohn et al., 2004; Frehner et al., 2005) and general expert knowledge. However, we are well aware that PNV distributions are also results of models, be it statistical models or thought models. Still we tend to favor these distributions over forest compositions derived from observations, 
e.g., of the InfoFlora (National Swiss Data and Information Center of the Swiss Flora, http://www.infoflora.ch, last access: 8 June 2014) or of National Forest Inventory (NFI) data (Brändli, 2009), because (a) the current forest composition is biased by management, such as favoring certain species (e.g., Picea abies) by selective thinning and planting, and (b) it would be challenging to extrapolate the plot-based NFI data in space. Furthermore, the existing LPJ-GUESS parameterization is according to a PNV. Hence, a comparison to actual forest dynamics would require taking into account management effects and would most likely cause additional changes to the LPJ-GUESS parameterization (e.g., reduced sensitivity of seedlings to chilling if trees are planted, i.e., surpass the seedling stage).

\subsubsection{Situation for the simulation year 2000}

The total biomass we modeled in general is slightly higher than the actual forest biomass. In Table 2 our results are compared with data from the Swiss NFI (Brändli, 2009). Our simulated total biomass for the Central Plateau is closest to the NFI data, whereas the results for the Jura and Alps differ more strongly from each other. Our total biomass results are also consistent with results of Erb (2004), who reported a PNV carbon mass of $12.4 \mathrm{kgC} \mathrm{m}^{-2}$ for Austrian forests. Furthermore, in a study where LPJ-GUESS was used locally for a valley in the Swiss Prealps, Gimmi et al. (2009) also concluded that the actual biomass was slightly smaller than the assumed natural forest biomass.

Simulations with the standard parameter set led to a species distribution that revealed that the parameterization was not specifically designed for the Alpine region. It might work better on larger scales (see also Hickler et al., 2012). For the specific climate, soil properties, terrain and present species this parameterization is not adapted enough. Important species were missing and the distribution of major species was not realistic. Using the standard parameter set, the spatial distribution of Picea abies ends too abruptly at altitudes of approximately $1000 \mathrm{~m}$. Here, it should build mixed forests with Abies alba (Brzeziecki et al., 1993; Bohn et al., 2004; Frehner et al., 2005). However, Abies alba did not establish at all. The most likely reason for its absence might be the combination of a low parameter value for the maximum 20-year coldest month mean temperature for establishment (high temperatures prevent establishment) and a high value of minimum growing degree day sum on $5^{\circ} \mathrm{C}$ base $\left(\mathrm{GDD}_{\min }\right.$, high temperatures are required for establishment; columns "tc_max_e" and "gdd5min" in Table D10 in the Appendix). With the standard parameter set, Pinus sylvestris appeared at the upper treeline. In contrast, according to PNV it is supposed to grow in the dry Alpine valleys (Bohn et al., 2004), and Larix decidua and Pinus cembra are the species that build up the upper treeline. In northern Europe, Pinus sylvestris reaches up to the northern treeline (e.g., Kullman, 2007). However, the distribution of Pinus sylvestris in the
Alps must be regarded separately from the one in northern Europe. The Scandinavian northern and Alpine upper treelines differ in terms of solar energy, angle of insolation, altitude, summer temperatures, wind magnitude, soil properties and the biota, which might have an influence on the species composition. Due to our information on Pinus sylvestris in the Alps we changed its parameters for our study. We particularly removed the limit for the maximum 20 -year coldest month mean temperature for establishment so that the species can also grow in the valleys (column "tc_max_e" in Table D10 in the Appendix). To force the growth of Pinus sylvestris, especially in the Alpine valleys, additional functions would have to be implemented into the model. Another parameter we changed for Pinus sylvestris was GDD $\mathrm{Din}_{\text {in }}$. We raised it from 500 to 600 to prevent growth at higher altitudes (column "gdd5min" in Table D10 in the Appendix). Generally, information on Pinus sylvestris $\mathrm{GDD}_{\min }$ in the literature reaches from 500 to 950 (Mikola, 1993; Rehfeldt et al., 2003; Matías and Jump, 2012). Considering a PNV, Fagus sylvat$i c a$ is the dominant species in the Central Plateau (Brzeziecki et al., 1993; Bohn et al., 2004; Frehner et al., 2005), but it is not exactly clear what grade of dominance is most realistic. There should be at least $50 \%$ Fagus sylvatica biomass but in most cases less than $10 \%$ of the biomass are of secondary tree species (Bohn et al., 2004). We decreased the drought tolerance of Fagus sylvatica (column "d_tol" in Table D10 in the Appendix). As a result, it is less abundant but still makes up approximately half of the forest biomass in the Central Plateau. With the standard parameterization set this value is higher but the species is too successful in dry regions where it should not appear under natural conditions (e.g., the east of the Valais). Another shortcoming of the standard parameter set is the low biomass of Betula pendula. We fixed that with the adjusted parameter set when we decreased the species' needed growing degree sum required for full leaf cover (column "phenramp" in Table D10 in the Appendix) to account for its comparatively fast budburst (Murray et al., 1989). The implementation of the new species was successful. The upper treeline composition with Larix decidua and Pinus cembra as main species, and the gradual downslope decrease of Larix decidua, is consistent to the expected distribution (Frehner et al., 2005).

\subsubsection{Development in the 21st century}

The total biomass increase of $1-2 \mathrm{kgC} \mathrm{m}^{-2}$ (equivalent to 40-80 $\mathrm{m}^{3}$ wood ha ${ }^{-1}$, see Sect. 2.5) is mainly $\mathrm{CO}_{2}$ driven, as simulations with a constant atmospheric $\mathrm{CO}_{2}$ show (see Fig. 9). An increase of temperature alone might have the effect of making more stands potentially habitable to more species but it also increases the evapotranspiration and thus the risk of water stress situations.

The fate of forest trees as a consequence of climate change does not only depend on species characteristics but also on the interspecific interactions (Walther, 2010). Our study 
strengthens this statement. Using the adjusted parameter set, the biomass of Pinus sylvestris and Quercus robur widely increased throughout the 21 st century. In contrast, using the standard set their biomass in general decreased. A likely reason for this is a strong increase in Fagus sylvatica biomass, favored by its unrealistically high drought tolerance, especially on sites initially populated by Pinus sylvestris (compare in Fig. 8 F.syl, right, with Fig. 5 P.syl). However, also with the adjusted parameter set, Pinus sylvestris first experienced a decrease starting in the first half of the 20th century (Fig. 3). It is not completely clear what triggered this decrease but it could be of complex origin. Most likely slight changes in the species composition play a role, since climatic events alone can be excluded because other less drought- or cold-resistant species were not affected. Nevertheless, in the second half of the 21st century a strong increase of Pinus sylvestris biomass occurred, yielding a positive increment for the whole simulation period. Interestingly, Pinus sylvestris is also one of the few species that increases its biomass on most stands even under a constant atmospheric $\mathrm{CO}_{2}$. Based on simulations with the LPJ-DGVM (same plant physiological functions as in LPJ-GUESS), Cheaib et al. (2012) reported a different result. They found that Pinus sylvestris in contrast to deciduous broadleaved trees benefits less from an increase in atmospheric $\mathrm{CO}_{2}$. However, our results show that statements of a general model behavior are critical when parameters are sensitive to small changes, and once more emphasize the importance of the species composition.

We most likely overestimated the increase in biomass for species establishing in new regions, because their future distribution will depend on migration rates, which we did not implement into the models used. This is in particular true for Quercus pubescens, which established on regions very distant to its origin (Fig. 3).

\section{Conclusions and outlook}

The results of our simulations can be regarded as a success towards (1) applying the GAPPARD method on a large scale, (2) advancing the complex forest model LPJ-GUESS, and (3) gaining insight into forest changes as a consequence of climate change. We were able to show that GAPPARD incorporates a computationally efficient method to analyze forest dynamics on large scales. Therefore, it represents a substantial advancement in forest modeling. The GAPPARD method could potentially be applied to every gap model that uses patch replacing disturbances. Thereby simulation time would decrease, and thus the potential simulation range can increase. Furthermore, it could be applied to other types of models to include the effect of stand-replacing small-scale disturbances.

One big future task is to find a way to allow spatial interconnectivity. In particular, it should be considered to find a way to include migration functions to improve the GAPPARD method. Moreover, it could further advance the method if the effect of disturbances that are not standreplacing will be implemented. To solve these issues and test the general applicability of GAPPARD, in the near future the method could be applied to other gap models, for example ForMind (Köhler and Huth, 1998). Furthermore, regional- to large-scale intercomparisons with the forest landscape model TreeMig (Lischke et al., 2006) are planned.

To further improve the applicability of LPJ-GUESS in Alpine landscapes, the newly found parameters and functions must be applied to different regions. It is furthermore relevant whether the new parameters and functions can also be applied on a larger scale and on regions with different climates. Such studies could also go hand in hand with analyses of the influence of different disturbance regimes on the modeling of forest dynamics, since the effect of different disturbance intervals can easily be applied.

In this paper, we successfully applied the GAPPARD method to simulate climate change effects on forest dynamics over the whole of Switzerland. We are optimistic that it can be used for any scale and any model that uses the gap model approach and that does not include interactions between neighboring grid cells or patch-to-patch interactions. Regardless of using GAPPARD or not, if applying LPJGUESS to different regions, one big challenge will be to parameterize all relevant species. 


\section{Appendix A: New plant physiological functions and parameters}

Based on Scherstjanoi et al. (2013) we included the three new tree species: Larix decidua, Pinus cembra and Pinus mugo. Existing functions of LPJ-GUESS were applied to both Pinus species. However, first plausibility tests showed that these functions were not sufficient for Larix decidua, mainly due to the tree species' specific phenology. In LPJGUESS, the foliage of summer-green species is transferred to the litter all at once on 1 simulation day (typically in fall) when the maximum number of equivalent days with full leaf cover per growing season exceeds a certain value. For most species, this approximation has no significant negative influence because photosynthetic efficiency in general is reduced more suddenly. However, especially for larches, leaf senescence can be a process that lasts for months during which photosynthetic intensity is reduced stepwise. Based on Migliavacca et al. (2008), Scherstjanoi et al. (2013) included this physiological trait by defining a new phenology type for Larix decidua. The tree species is modeled like a summer-green species, but in autumn the phenological state of the larches will decrease with an s-shaped curve. Here, we improved this function to make it more applicable for more varying climate conditions. For means of simplification, we decided to define a time point in a year when the process of leaf senescence will be completed, independently of climate conditions. This is also in accordance with the findings of Migliavacca et al. (2008), who reported that Larix decidua trees of different stands complete leaf senescence roughly at the same time, independently of the senescence curve. We decided to use 1 December as that day. We then calculated the phenology of Larix decidua depending on the number of days since the start of fall of leaves $t_{\mathrm{ls}}$ and the length of the period between the start of fall of leaves and 1 December $d_{\mathrm{ls}}$ :

$\operatorname{phen}(t)=\frac{1}{1+0.5 e^{\left(\frac{13.5}{d_{\mathrm{ls}}} t_{\mathrm{ls}}-6.75\right)}}$,

so that phen $(t)$ is close to 1 when the ratio of $t_{\mathrm{ls}}$ to $d_{\mathrm{ls}}$ is approaching 0 , and close to 0 when the ratio is close to 1 .

According to Scherstjanoi et al. (2013), we defined Larix decidua as a shade-intolerant species with a high ratio of leaf area to sapwood cross-sectional area (Oren et al., 1995). The parameters of the new Pinus species are mainly based on $P i$ nus sylvestris parameters. However, both new Pinus species are more cold resistant, have seeds that are less drought resistant and their needles have a higher longevity. Moreover, Pinus mugo was defined as shade intolerant.

In the establishment function, we changed the functionality of the LPJ-GUESS parameter of maximum 20-year coldest month mean temperature for establishment (tc_max_e), which prevents certain boreal species from growing in temperate stands. Instead of this threshold function used so far, for lowest mean monthly temperatures for the last 20 years (mt_min in Celsius degrees) above tc_max_e, saplings now can establish. Their number $n$ then decreases according to an s-shaped curve:

$n=\frac{n_{0}}{1+0.5 e^{\left.\left(\mathrm{tc} \_ \text {max } \_ \text {(mt } m \text { min }-\mathrm{tc} \_ \text {max } \_ \text {e }\right)-4.5\right)}}$,

with tc_max_f being a newly introduced plant-specific shape parameter that influences how intense the reduction of sapling establishment is (Table D10), and $n_{0}$ being the number of saplings that establish when $m t_{-}$min is below tc_max_e.

A summary of all parameters used is given in Tables D8D10.

\section{Appendix B: Calculation of the root mean square error}

The differences in carbon mass of one species between the two model outputs $\left(C_{\mathrm{m} 1}, C_{\mathrm{m} 2}\right)$ are added up for each year (y) between 1901 and 2100. These, for each year calculated differences:

$c_{\mathrm{md}, y}=C_{\mathrm{m} 1, y}-C_{\mathrm{m} 2, y}$,

are scaled by the mean maximum carbon mass appearing in the period defined by the time window:

$$
\begin{gathered}
c_{\mathrm{mm}}=\max \left(C_{\mathrm{m} 1,1901}, C_{\mathrm{m} 2,1901}, C_{\mathrm{m} 1,1902}, C_{\mathrm{m} 2,1902}, \ldots,\right. \\
\left.C_{\mathrm{m} 1,2100}, C_{\mathrm{m} 2,2100}\right) .
\end{gathered}
$$

Then its square is added up and divided by the number of years in which the species had a positive biomass in either of both models ( $y_{\text {count }}$ ); and the root of it is the root mean square error:

RMSE $=\sqrt{\frac{\sum_{y=y_{\text {start }}}^{y_{\text {end }}}\left(\frac{C_{\mathrm{md}, y}}{C_{\mathrm{mm}}}\right)^{2}}{y_{\text {count }}} .}$

\section{Appendix C: LPJ-GUESS input data}

\section{C1 Cloud coverage}

In LPJ-GUESS, either daily cloud coverage or total net radiation is needed as an input to calculate the net primary carbon uptake. No data in the wanted resolution were available to us on either of them. However, upscaled radiation data are often not correlated to precipitation data, so that unrealistic input is produced (e.g., precipitation without cloud coverage). One possibility would have been to apply advanced geostatistical methods for the interpolation of the precipitation and net radiation between climate stations.

For means of simplicity, we used the available climate data from 59 Swiss weather stations (Table D1) to be able to predict cloud coverage for all kilometer grid cells using an empirical probability distribution density coded as a set of 
lookup tables. We discretized six cloud coverage classes to be predicted and applied three discretized explanatory variables: precipitation in a day, season and altitude. For each combination of explanatory variables (5 precipitation classes $\times 5$ altitudinal classes $\times 4$ seasons) we calculated probabilities of each of the six cloud coverage classes derived from the weather station data frequency and thus created the lookup tables (Tables D2-D6). During the simulation, one cloud coverage class for a simulation day was picked depending on the three explanatory variables. If, for example, no cloud cover for a certain day is predicted with a probability of $25 \%$, the lowest cloud coverage class will be taken if a random number between 0 and 1 is smaller than 0.25 . After the cloud coverage class has been determined, the value is sampled randomly between the border values of the class.

\section{C2 Soil data}

The soil of simulated stands in LPJ-GUESS is described by a code number (see Table A6.3 in Prentice et al., 1992). With this soil code, the values of five different soil characteristics are identified (Table D7, columns "ep-t3"). We used the soil suitability map of Switzerland (Frei, 1976) and general knowledge to estimate the LPJ-GUESS soil code (Table D7, column un) based on Sect. 5.3.3 of Jury et al. (1991). As a result a soil code number was attached to each simulated grid cell (Fig. D1). 


\section{Appendix D: Tables and figures}

Table D1. Climate station data used to estimate cloud coverage. lat and long: latitude and longitude in meters, CH1903/lv03 (Swiss) coordinates; alt: altitude above sea level in meters; ys: first year of cloud coverage recording; ye: last year of cloud coverage recording. When cloud coverage was recorded at a station, precipitation was also recorded.

\begin{tabular}{|c|c|c|c|c|c|}
\hline & lat & long & alt & ys & ye \\
\hline Aadorf/Tänikon & 710500 & 259820 & 536 & 1971 & 2007 \\
\hline Acquarossa/Comprovasco & 714998 & 146440 & 575 & 1959 & 1976 \\
\hline Adelboden & 609400 & 148975 & 1320 & 1966 & 2011 \\
\hline Aigle & 560120 & 130630 & 381 & 1981 & 2011 \\
\hline Altdorf & 690960 & 191700 & 449 & 1901 & 2011 \\
\hline Basel/Binningen & 610850 & 265620 & 316 & 1901 & 2011 \\
\hline Bern/Zollikofen & 601930 & 204410 & 553 & 1901 & 2011 \\
\hline Buchs/Aarau & 648400 & 248380 & 387 & 1984 & 2011 \\
\hline Buffalora & 816500 & 170250 & 1970 & 1964 & 1997 \\
\hline Chur & 759471 & 193157 & 556 & 1931 & 2011 \\
\hline Col du Grand St Bernard & 579200 & 79720 & 2472 & 1901 & 2011 \\
\hline Davos & 783580 & 187480 & 1590 & 1901 & 2005 \\
\hline Disentis/Sedrun & 708200 & 173800 & 1190 & 1961 & 2011 \\
\hline Engelberg & 674150 & 186060 & 1035 & 1931 & 1996 \\
\hline Evolène/Villa & 605415 & 106740 & 1825 & 1986 & 2011 \\
\hline Fahy & 562460 & 252650 & 596 & 1981 & 2007 \\
\hline Fey & 586725 & 115180 & 737 & 1959 & 1979 \\
\hline Genève-Cointrin & 498580 & 122320 & 420 & 1958 & 2011 \\
\hline Glarus & 723800 & 210600 & 515 & 1931 & 1996 \\
\hline Grimsel Hospiz & 668580 & 158210 & 1980 & 1964 & 2011 \\
\hline Gütsch ob Andermatt & 690140 & 167590 & 2287 & 1958 & 2003 \\
\hline Güttingen & 738430 & 273950 & 440 & 1976 & 1997 \\
\hline Hinterrhein & 733900 & 153980 & 1611 & 1968 & 1996 \\
\hline Interlaken & 633070 & 169120 & 580 & 1931 & 1997 \\
\hline Jungfraujoch & 641930 & 155275 & 3580 & 1933 & 2011 \\
\hline La Brévine & 537000 & 203980 & 1050 & 1966 & 1996 \\
\hline La Chaux-de-Fonds & 551290 & 215150 & 1018 & 1901 & 2011 \\
\hline La Dôle & 497050 & 142380 & 1670 & 1973 & 1993 \\
\hline Leibstadt & 656350 & 272100 & 341 & 2004 & 2006 \\
\hline Locarno/Monti & 704167 & 114313 & 383 & 1935 & 2011 \\
\hline Lugano & 717880 & 95870 & 273 & 1901 & 2011 \\
\hline Luzern & 665520 & 209860 & 456 & 1931 & 2007 \\
\hline Magadino/Cadenazzo & 715475 & 113162 & 203 & 1958 & 2010 \\
\hline Montana & 603600 & 129160 & 1508 & 1931 & 1996 \\
\hline Neuchâtel & 563150 & 205600 & 485 & 1901 & 2006 \\
\hline Nyon/Changins & 507280 & 139170 & 430 & 1965 & 1977 \\
\hline Payerne & 562150 & 184855 & 490 & 1964 & 2011 \\
\hline Pilatus & 661910 & 203410 & 2106 & 1981 & 1998 \\
\hline Piotta & 694930 & 152500 & 1007 & 1979 & 2011 \\
\hline Plaffeien & 586850 & 177400 & 1042 & 1989 & 1995 \\
\hline Poschiavo/Robbia & 801850 & 136180 & 1078 & 1961 & 2011 \\
\hline PSI Würenlingen & 659540 & 265600 & 334 & 2004 & 2005 \\
\hline Pully & 540820 & 151500 & 461 & 1978 & 1995 \\
\hline Säntis & 744100 & 234900 & 2502 & 1901 & 2011 \\
\hline Samedan & 787149 & 155701 & 1709 & 1980 & 2011 \\
\hline S. Bernardino & 734120 & 147270 & 1639 & 1968 & 2010 \\
\hline Schaffhausen & 688700 & 282800 & 437 & 1931 & 2011 \\
\hline Scuol & 817130 & 186400 & 1298 & 1931 & 2005 \\
\hline Sion & 592200 & 118625 & 482 & 1958 & 2011 \\
\hline Stabio & 716040 & 77970 & 353 & 1981 & 1990 \\
\hline St. Gallen & 747940 & 254600 & 779 & 1931 & 2011 \\
\hline Ulrichen & 666740 & 150760 & 1345 & 1984 & 2011 \\
\hline Vaduz & 757720 & 221720 & 460 & 1971 & 2011 \\
\hline Visp & 631150 & 128020 & 640 & 1980 & 1995 \\
\hline Weissfluhjoch & 780600 & 189630 & 2690 & 1959 & 2008 \\
\hline Wynau & 626400 & 233860 & 422 & 1978 & 2009 \\
\hline Zermatt & 624300 & 97575 & 1638 & 1960 & 2003 \\
\hline Zürich/Fluntern & 685125 & 248090 & 556 & 1901 & 2011 \\
\hline Zürich/Kloten & 682720 & 259340 & 436 & 1958 & 2011 \\
\hline
\end{tabular}


Table D2. Probabilities of cloud coverage classes for a $24 \mathrm{~h}$ precipitation sum of $0 \mathrm{~cm}$ depending on explanatory variables following selected Swiss climate weather stations. A: altitude of the climate stations; S: season; wi: winter (before day 46 or after day 319 of a year); sp: spring (between days 46 and 136 of a year); su: summer (between days 137 and 227 of a year); fa: fall (between days 228 and 318 of a year); I-IV: cloud coverage classes; I: 0\%; II: 0-20\%; III: 20-40\%; IV: 40-60\%; V: 60-80\%; VI: 80-100\% cloud coverage.

\begin{tabular}{llrrrrrr}
\hline $\mathrm{A}$ & $\mathrm{S}$ & $\mathrm{I}$ & $\mathrm{II}$ & $\mathrm{III}$ & $\mathrm{IV}$ & $\mathrm{V}$ & $\mathrm{VI}$ \\
\hline$<500 \mathrm{~m}$ & wi & 0.0816 & 0.1248 & 0.1367 & 0.1434 & 0.1634 & 0.3501 \\
& sp & 0.0676 & 0.1646 & 0.1870 & 0.2000 & 0.1977 & 0.1830 \\
& su & 0.0393 & 0.2196 & 0.2653 & 0.2285 & 0.1672 & 0.0802 \\
& fa & 0.0555 & 0.1591 & 0.2092 & 0.2139 & 0.1847 & 0.1775 \\
\hline $500-$ & wi & 0.0782 & 0.1089 & 0.1413 & 0.1567 & 0.1864 & 0.3285 \\
$<1000 \mathrm{~m}$ & sp & 0.0688 & 0.1568 & 0.1777 & 0.1979 & 0.2142 & 0.1846 \\
& su & 0.0409 & 0.2194 & 0.2487 & 0.2288 & 0.1741 & 0.0880 \\
& fa & 0.0587 & 0.1560 & 0.2055 & 0.2147 & 0.1979 & 0.1672 \\
\hline $1000-$ & wi & 0.2423 & 0.1816 & 0.1872 & 0.1576 & 0.1222 & 0.1091 \\
$<1500 \mathrm{~m}$ & sp & 0.1146 & 0.1630 & 0.1956 & 0.1949 & 0.1815 & 0.1503 \\
& su & 0.0395 & 0.1821 & 0.2745 & 0.2423 & 0.1805 & 0.0812 \\
& fa & 0.1107 & 0.1968 & 0.2325 & 0.2004 & 0.1594 & 0.1002 \\
\hline $1500-$ & wi & 0.2494 & 0.2080 & 0.1897 & 0.1496 & 0.1237 & 0.0796 \\
$<2000 \mathrm{~km}$ & sp & 0.1229 & 0.1717 & 0.1926 & 0.1904 & 0.1826 & 0.1397 \\
& su & 0.0449 & 0.1816 & 0.2727 & 0.2489 & 0.1772 & 0.0747 \\
& fa & 0.1270 & 0.1964 & 0.2271 & 0.2109 & 0.1559 & 0.0827 \\
\hline$>2000 \mathrm{~m}$ & wi & 0.1958 & 0.2911 & 0.1946 & 0.1495 & 0.1030 & 0.0660 \\
& sp & 0.1003 & 0.2178 & 0.1984 & 0.1849 & 0.1705 & 0.1280 \\
& su & 0.0373 & 0.1874 & 0.2444 & 0.2435 & 0.1795 & 0.1079 \\
& fa & 0.0888 & 0.2206 & 0.2300 & 0.2114 & 0.1591 & 0.0901 \\
\hline
\end{tabular}

Table D3. Probabilities of cloud coverage classes for a $24 \mathrm{~h}$ precipitation sum of $>0-4 \mathrm{~cm}$ depending on explanatory variables following selected Swiss climate stations. For further description see Table D2.

\begin{tabular}{llrrrrrr}
\hline $\mathrm{A}$ & $\mathrm{S}$ & $\mathrm{I}$ & $\mathrm{II}$ & $\mathrm{III}$ & $\mathrm{IV}$ & $\mathrm{V}$ & $\mathrm{VI}$ \\
\hline$<500 \mathrm{~m}$ & $\mathrm{Wi}$ & 0.0012 & 0.0054 & 0.0281 & 0.0815 & 0.2068 & 0.6770 \\
& $\mathrm{Sp}$ & 0.0003 & 0.0047 & 0.0305 & 0.1095 & 0.2653 & 0.5897 \\
& $\mathrm{Su}$ & 0.0014 & 0.0141 & 0.0785 & 0.1946 & 0.3245 & 0.3869 \\
& $\mathrm{Fa}$ & 0.0037 & 0.0126 & 0.0566 & 0.1473 & 0.2922 & 0.4875 \\
\hline $500-$ & Wi & 0.0004 & 0.0032 & 0.0255 & 0.0876 & 0.2235 & 0.6598 \\
$<1000 \mathrm{~m}$ & $\mathrm{Sp}$ & 0.0002 & 0.0036 & 0.0246 & 0.1034 & 0.2696 & 0.5986 \\
& $\mathrm{Su}$ & 0.0002 & 0.0114 & 0.0685 & 0.1859 & 0.3366 & 0.3974 \\
& $\mathrm{Fa}$ & 0.0015 & 0.0104 & 0.0459 & 0.1421 & 0.3135 & 0.4866 \\
\hline $1000-$ & $\mathrm{Wi}$ & 0.0061 & 0.0139 & 0.0527 & 0.1199 & 0.2406 & 0.5668 \\
$<1500 \mathrm{~m}$ & $\mathrm{Sp}$ & 0.0012 & 0.0062 & 0.0396 & 0.1157 & 0.2541 & 0.5832 \\
& $\mathrm{Su}$ & 0.0016 & 0.0117 & 0.0697 & 0.1974 & 0.3214 & 0.3983 \\
& $\mathrm{Fa}$ & 0.0027 & 0.0143 & 0.0629 & 0.1627 & 0.2812 & 0.4761 \\
\hline $1500-$ & $\mathrm{Wi}$ & 0.0060 & 0.0165 & 0.0598 & 0.1420 & 0.2636 & 0.5121 \\
$<2000 \mathrm{~m}$ & $\mathrm{Sp}$ & 0.0018 & 0.0109 & 0.0406 & 0.1168 & 0.2477 & 0.5821 \\
& $\mathrm{Su}$ & 0.0006 & 0.0122 & 0.0749 & 0.2051 & 0.3207 & 0.3865 \\
& $\mathrm{Fa}$ & 0.0019 & 0.0169 & 0.0602 & 0.1631 & 0.3015 & 0.4564 \\
\hline$>=2000 \mathrm{~m}$ & $\mathrm{Wi}$ & 0.0154 & 0.0406 & 0.0907 & 0.1598 & 0.2702 & 0.4234 \\
& $\mathrm{Sp}$ & 0.0047 & 0.0126 & 0.0505 & 0.1211 & 0.2765 & 0.5345 \\
& $\mathrm{Su}$ & 0.0025 & 0.0117 & 0.0472 & 0.1649 & 0.2961 & 0.4776 \\
& $\mathrm{Fa}$ & 0.0038 & 0.0151 & 0.0582 & 0.1485 & 0.2901 & 0.4843 \\
\hline
\end{tabular}


Table D4. Probabilities of cloud coverage classes for a $24 \mathrm{~h}$ precipitation sum of $>4-10 \mathrm{~cm}$ depending on explanatory variables following selected Swiss climate stations. For further description see Table D2.

\begin{tabular}{llrrrrrr}
\hline $\mathrm{A}$ & $\mathrm{S}$ & $\mathrm{I}$ & $\mathrm{II}$ & $\mathrm{III}$ & $\mathrm{IV}$ & $\mathrm{V}$ & $\mathrm{VI}$ \\
\hline$<500 \mathrm{~m}$ & $\mathrm{Wi}$ & 0 & 0.0002 & 0.0070 & 0.0339 & 0.1409 & 0.8179 \\
& $\mathrm{Sp}$ & 0 & 0.0006 & 0.0073 & 0.0440 & 0.1664 & 0.7817 \\
& $\mathrm{Su}$ & 0.0002 & 0.0043 & 0.0378 & 0.1197 & 0.2644 & 0.5736 \\
& $\mathrm{Fa}$ & 0.0005 & 0.0038 & 0.0204 & 0.0790 & 0.2161 & 0.6801 \\
\hline $500-$ & $\mathrm{Wi}$ & 0 & 0 & 0.0041 & 0.0303 & 0.1657 & 0.7998 \\
$<1000 \mathrm{~m}$ & $\mathrm{Sp}$ & 0 & 0.0004 & 0.0076 & 0.0396 & 0.1759 & 0.7765 \\
& $\mathrm{Su}$ & 0 & 0.0045 & 0.0267 & 0.1095 & 0.2731 & 0.5862 \\
& $\mathrm{Fa}$ & 0.0010 & 0.0015 & 0.0130 & 0.0713 & 0.2448 & 0.6685 \\
\hline $1000-$ & $\mathrm{Wi}$ & 0 & 0 & 0.0113 & 0.0388 & 0.1582 & 0.7916 \\
$<1500 \mathrm{~m}$ & $\mathrm{Sp}$ & 0 & 0 & 0.0069 & 0.0365 & 0.1448 & 0.8118 \\
& $\mathrm{Su}$ & 0.0004 & 0.0021 & 0.0367 & 0.1356 & 0.2512 & 0.5740 \\
& $\mathrm{Fa}$ & 0 & 0.0024 & 0.0200 & 0.0871 & 0.2159 & 0.6747 \\
\hline $1500-$ & $\mathrm{Wi}$ & 0.0007 & 0 & 0.0110 & 0.0542 & 0.1670 & 0.7670 \\
$<2000 \mathrm{~m}$ & $\mathrm{Sp}$ & 0 & 0.0007 & 0.0078 & 0.0501 & 0.1482 & 0.7932 \\
& $\mathrm{Su}$ & 0.0005 & 0.0046 & 0.0250 & 0.1287 & 0.2431 & 0.5981 \\
& $\mathrm{Fa}$ & 0.0007 & 0.0026 & 0.0216 & 0.0778 & 0.2085 & 0.6889 \\
\hline$>=2000 \mathrm{~m}$ & $\mathrm{Wi}$ & 0.0025 & 0.0034 & 0.0211 & 0.0684 & 0.2466 & 0.6579 \\
& $\mathrm{Sp}$ & 0 & 0.0021 & 0.0084 & 0.0505 & 0.1593 & 0.7796 \\
& $\mathrm{Su}$ & 0 & 0.0006 & 0.0280 & 0.0784 & 0.2298 & 0.6632 \\
& $\mathrm{Fa}$ & 0.0008 & 0.0008 & 0.0188 & 0.0776 & 0.1951 & 0.7069 \\
\hline
\end{tabular}

Table D5. Probabilities of cloud coverage classes for a $24 \mathrm{~h}$ precipitation sum of $>10-20 \mathrm{~cm}$ depending on explanatory variables following selected Swiss climate stations. For further description see Table D2.

\begin{tabular}{llrrrrrr}
\hline $\mathrm{A}$ & $\mathrm{S}$ & $\mathrm{I}$ & $\mathrm{II}$ & $\mathrm{III}$ & $\mathrm{IV}$ & $\mathrm{V}$ & $\mathrm{VI}$ \\
\hline$<500 \mathrm{~m}$ & $\mathrm{Wi}$ & 0 & 0.0002 & 0.0070 & 0.0339 & 0.1409 & 0.8179 \\
& $\mathrm{Sp}$ & 0 & 0.0006 & 0.0073 & 0.0440 & 0.1664 & 0.7817 \\
& $\mathrm{Su}$ & 0.0002 & 0.0043 & 0.0378 & 0.1197 & 0.2644 & 0.5736 \\
& $\mathrm{Fa}$ & 0.0005 & 0.0038 & 0.0204 & 0.0790 & 0.2161 & 0.6801 \\
\hline $500-$ & $\mathrm{Wi}$ & 0 & 0 & 0.0041 & 0.0303 & 0.1657 & 0.7998 \\
$<1000 \mathrm{~m}$ & $\mathrm{Sp}$ & 0 & 0.0004 & 0.0076 & 0.0396 & 0.1759 & 0.7765 \\
& $\mathrm{Su}$ & 0 & 0.0045 & 0.0267 & 0.1095 & 0.2731 & 0.5862 \\
& $\mathrm{Fa}$ & 0.0010 & 0.0015 & 0.0130 & 0.0713 & 0.2448 & 0.6685 \\
\hline $1000-$ & $\mathrm{Wi}$ & 0 & 0 & 0.0113 & 0.0388 & 0.1582 & 0.7916 \\
$<1500 \mathrm{~m}$ & $\mathrm{Sp}$ & 0 & 0 & 0.0069 & 0.0365 & 0.1448 & 0.8118 \\
& $\mathrm{Su}$ & 0.0004 & 0.0021 & 0.0367 & 0.1356 & 0.2512 & 0.5740 \\
& $\mathrm{Fa}$ & 0 & 0.0024 & 0.0200 & 0.0871 & 0.2159 & 0.6747 \\
\hline $1500-$ & $\mathrm{Wi}$ & 0.0007 & 0 & 0.0110 & 0.0542 & 0.1670 & 0.7670 \\
$<2000 \mathrm{~m}$ & $\mathrm{Sp}$ & 0 & 0.0007 & 0.0078 & 0.0501 & 0.1482 & 0.7932 \\
& $\mathrm{Su}$ & 0.0005 & 0.0046 & 0.0250 & 0.1287 & 0.2431 & 0.5981 \\
& $\mathrm{Fa}$ & 0.0007 & 0.0026 & 0.0216 & 0.0778 & 0.2085 & 0.6889 \\
\hline$>=2000 \mathrm{~m}$ & $\mathrm{Wi}$ & 0.0025 & 0.0034 & 0.0211 & 0.0684 & 0.2466 & 0.6579 \\
& $\mathrm{Sp}$ & 0 & 0.0021 & 0.0084 & 0.0505 & 0.1593 & 0.7796 \\
& $\mathrm{Su}$ & 0 & 0.0006 & 0.0280 & 0.0784 & 0.2298 & 0.6632 \\
& $\mathrm{Fa}$ & 0.0008 & 0.0008 & 0.0188 & 0.0776 & 0.1951 & 0.7069 \\
\hline
\end{tabular}


Table D6. Probabilities of cloud coverage classes for a $24 \mathrm{~h}$ precipitation sum of $>20 \mathrm{~cm}$ depending on explanatory variables following selected Swiss climate stations. For further description see Table D2.

\begin{tabular}{|c|c|c|c|c|c|c|c|}
\hline A & $S$ & I & II & III & IV & V & VI \\
\hline \multirow[t]{4}{*}{$<500 \mathrm{~m}$} & $\mathrm{Wi}$ & 0 & 0 & 0 & 0.0019 & 0.0393 & 0.9588 \\
\hline & $\mathrm{Sp}$ & 0 & 0 & 0.0008 & 0.0068 & 0.0462 & 0.9462 \\
\hline & $\mathrm{Su}$ & 0 & 0.0004 & 0.0198 & 0.0757 & 0.1713 & 0.7327 \\
\hline & $\mathrm{Fa}$ & 0 & 0.0005 & 0.0097 & 0.0353 & 0.1078 & 0.8468 \\
\hline 500 & $\mathrm{Wi}$ & 0 & 0 & 0 & 0.0024 & 0.0217 & 0.9759 \\
\hline \multirow[t]{3}{*}{$<1000 \mathrm{~m}$} & $\mathrm{Sp}$ & 0 & 0 & 0.0045 & 0.0135 & 0.0655 & 0.9165 \\
\hline & $\mathrm{Su}$ & 0 & 0.0020 & 0.0153 & 0.0675 & 0.1554 & 0.7597 \\
\hline & $\mathrm{Fa}$ & 0 & 0 & 0.0075 & 0.0313 & 0.1314 & 0.8298 \\
\hline 1000 & $\mathrm{Wi}$ & 0 & 0 & 0 & 0.0035 & 0.0318 & 0.9647 \\
\hline \multirow[t]{3}{*}{$<1500 \mathrm{~m}$} & $\mathrm{Sp}$ & 0 & 0 & 0 & 0.0069 & 0.0466 & 0.9465 \\
\hline & $\mathrm{Su}$ & 0 & 0 & 0.0181 & 0.0683 & 0.1215 & 0.7922 \\
\hline & $\mathrm{Fa}$ & 0 & 0 & 0.0031 & 0.0251 & 0.0868 & 0.8849 \\
\hline 1500 & $\mathrm{Wi}$ & 0 & 0 & 0 & 0.0014 & 0.0360 & 0.9626 \\
\hline \multirow[t]{3}{*}{$<2000 \mathrm{~m}$} & $\mathrm{Sp}$ & 0 & 0 & 0 & 0.0061 & 0.0167 & 0.9772 \\
\hline & $\mathrm{Su}$ & 0 & 0 & 0.0060 & 0.0518 & 0.0976 & 0.8446 \\
\hline & $\mathrm{Fa}$ & 0 & 0 & 0.0011 & 0.0139 & 0.0622 & 0.9227 \\
\hline \multirow[t]{4}{*}{$>=2000 \mathrm{~m}$} & Wi & 0 & 0 & 0.0018 & 0.0062 & 0.0677 & 0.9244 \\
\hline & $\mathrm{Sp}$ & 0 & 0 & 0.0010 & 0.0089 & 0.0546 & 0.9355 \\
\hline & $\mathrm{Su}$ & 0 & 0 & 0.0041 & 0.0386 & 0.1269 & 0.8305 \\
\hline & $\mathrm{Fa}$ & 0 & 0 & 0.0057 & 0.0149 & 0.0744 & 0.9050 \\
\hline
\end{tabular}

Table D7. Soil classification. sc: LPJ-GUESS soil code; ep: empirical parameter in percolation equation (mm day ${ }^{-1}$ ); vw: volumetric water holding capacity (WHC) at field capacity minus WHC at wilting point, as fraction of soil layer depth; t1-t3: thermal diffusivities (TD; in $\left.\mathrm{mm}^{2} \mathrm{~s}^{-1}\right)$; $\mathrm{t} 1$ : TD at wilting point $(0 \% \mathrm{WHC})$; t2: TD at $15 \%$ WHC; $\mathrm{t} 3$ : TD at field capacity (100\% WHC). Thermal diffusivities follow van Duin (1963) and Jury et al. (1991, Fig. 5.11.); un: unit number in soil suitability map.

\begin{tabular}{rrrrrrl}
\hline sc & ep & vw & t1 & t2 & t3 & un \\
\hline 1 & 5.0 & 0.110 & 0.2 & 0.800 & 0.4 & B3, E3, L1, P1, P4, P7, Q2, Q5, R2, R5, S1, S5, S7, T1, T3, U1, U2, U3, \\
& & & & & & U5, U7, V1, V2, V3, V4, V5, V6, V7, V8, W1, W2, W3, W5, W7, \\
& & & & & & W8, Y2, Y5, Z2 \\
2 & 4.0 & 0.150 & 0.2 & 0.650 & 0.4 & A7, A8, A9, B7, C3, C6, H1, O2, Q1 \\
3 & 3.0 & 0.120 & 0.2 & 0.500 & 0.4 & A1, A3, B1, C5, C7, C8, D1, E2, E4, E5, E7, F3 \\
4 & 4.5 & 0.130 & 0.2 & 0.725 & 0.4 & F2, F4, G1, G2, H3, H7, J2, K3, L2, L3, L4, M1, M3, N1, N3, P8, R1, \\
& & & & & & R4, S2, S3, S4, S6, S8, T2, T4, U4, U6, U8, W4, W6, X2, Y1, Y4, Z3, Z4 \\
5 & 4.0 & 0.115 & 0.2 & 0.650 & 0.4 & B6, C2, E1, E6, E8 \\
6 & 3.5 & 0.135 & 0.2 & 0.575 & 0.4 & A4, A5, B2, B4, B5, B8, B9, C1, C4, D2, G3, G4, H2, H4, H5, H6, J1, \\
& & & & & & K1, K2, K4, M2, M4, N2, N4, O1, O3, O4, O5, P2, P3, P5, P6, Q4, R3 \\
& & & & & & X1, Y3, Z1, Z5 \\
7 & 4.0 & 0.127 & 0.2 & 0.650 & 0.4 & A6, E9, F1 \\
8 & 9.0 & 0.300 & 0.1 & 0.100 & 0.1 & Q3 \\
9 & 0.2 & 0.100 & 0.2 & 0.500 & 0.4 & A2 \\
\hline
\end{tabular}


Table D8. Shade tolerance parameters. The affiliations to species are given in Table D10. st: shade tolerant; ns: nearly shade tolerant; ist: intermediate shade tolerant; si: shade intolerant; siBES: shade-intolerant boreal evergreen shrubs.

\begin{tabular}{lrrrrr}
\hline & st & ns & ist & si & siBES \\
\hline $\begin{array}{l}\text { Minimum forest-floor PAR } \\
\text { for establishment }\left(\mathrm{MJ} \mathrm{m}^{-2} \text { day }^{-1}\right)\end{array}$ & 1.25 & 1.625 & 2 & 2.5 & 1.5 \\
$\begin{array}{l}\text { Growth efficiency threshold } \\
\text { kgC m }^{-2} \text { year }^{-1} \text { ) }\end{array}$ & 0.04 & 0.06 & 0.08 & 0.1 & 0.04 \\
$\begin{array}{l}\text { Maximum establishment rate } \\
\text { (saplings m }\end{array}$ year $^{-1}$ ) & 0.05 & 0.075 & 0.1 & 0.2 & 0.625 \\
$\begin{array}{l}\text { Recruitment shape parameter } \\
\text { after Fulton (1991) }\end{array}$ & 2 & 4 & 6 & 10 & 10 \\
$\begin{array}{l}\text { Annual sapwood to heartwood } \\
\text { turnover rate (year }\end{array}$ & 0.05 & 0.0575 & 0.065 & 0.08 & 0.0125 \\
\hline
\end{tabular}

Table D9. Climatic range parameters. The affiliations to species are shown in Table D10.

\begin{tabular}{lll}
\hline & Boreal & Temperate \\
\hline $\begin{array}{l}\text { Optimal temperature range } \\
\text { for photosynthesis }\left({ }^{\circ} \mathrm{C}\right)\end{array}$ & 10 to 25 & 15 to 25 \\
\hline $\begin{array}{l}\text { Maximum temperature range } \\
\text { for photosynthesis }\left({ }^{\circ} \mathrm{C}\right)\end{array}$ & -4 to 38 & -2 to 38 \\
\hline
\end{tabular}


Table D10. Specific tree parameters of I the standard and II the adjusted parameter set. One entry per species and parameter means the same parameters were used for both sets or that the species was not included in the standard parameter set (newly added species). * newly added species; ** direct comparison between I and II not meaningful because different establishment functions were used; n.i.: parameter not implemented. b: boreal; t: temperate; st: shade tolerant; ns: nearly shade tolerant; ist: intermediate shade tolerant; si: shade intolerant; e: evergreen; s: summer-green; d: summer-green with decelerated senescence; cl.range: climatic range; shade tol.: shade tolerance; ph.type: phenology type; phenramp: growing degree sum on $5{ }^{\circ} \mathrm{C}$ base required for full leaf cover; k_latosa: ratio of leaf area to sapwood crosssectional area; rootdist_u and rootdist_l: proportion of fine roots extending into upper and lower soil layers; leaflong: leaf longevity; chill_b: changed chilling parameter (Sykes et al., 1996); d_tol: drought tolerance, lower values show higher tolerance (minimum soil water content needed for establishment, averaged over the growing season and expressed as a fraction of available water holding capacity, and water uptake efficiency); gdd5min: minimum growing degree day sum on $5{ }^{\circ} \mathrm{C}$ base, tc_max_e and tc_min_e: maximum and minimum 20 -year coldest month mean temperature for establishment; tc_max_f: shape parameter for new tc_max_e function (see Appendix A); tc_min_s: maximum 20-year coldest month mean temperature for survival; k_allom2: steepness-influencing parameter in diameter to height relation; BES: boreal evergreen shrubs; B.pub: Betula pubescens; L.dec: Larix decidua; P.abi: Picea abies; P.cem: Pinus cembra; P.mug: Pinus mugo; P.syl: Pinus sylvestris; A.alb: Abies alba; B.pen: Betula pendula; C.bet: Carpinus betulus; C.ave: Corylus avellana; F.syl: Fagus sylvatica; F.exc: Fraxinus excelsior; Q.pub: Quercus pubescens; Q.rob: Quercus robur; T.cor: Tilia cordata.

\begin{tabular}{|c|c|c|c|c|c|c|c|c|c|}
\hline & & BES & B.pub & L.dec* & P.abi & P.cem* & P.mug* & P.syl & A.alb \\
\hline shade tol. & $\begin{array}{c}\text { I } \\
\text { II }\end{array}$ & si & si & si & $\begin{array}{l}\mathrm{st} \\
\mathrm{ns}\end{array}$ & ist & si & ist & st \\
\hline k_latosa & & 300 & 5000 & 5000 & 4000 & 2000 & 2000 & 2000 & 4000 \\
\hline d_tol & $\begin{array}{c}\text { I } \\
\text { II }\end{array}$ & 0.25 & 0.5 & 0.3 & $\begin{array}{l}0.43 \\
0.38\end{array}$ & 0.3 & 0.3 & 0.25 & $\begin{array}{l}0.35 \\
0.33\end{array}$ \\
\hline gdd5min & $\begin{array}{c}\text { I } \\
\text { II }\end{array}$ & 200 & 350 & 300 & 600 & 300 & 400 & $\begin{array}{l}500 \\
600\end{array}$ & $\begin{array}{l}1450 \\
900\end{array}$ \\
\hline tc_max_e ${ }^{* *}$ & $\begin{array}{c}\text { I } \\
\text { II }\end{array}$ & -2 & - & -2 & $\begin{array}{l}-1.5 \\
-3\end{array}$ & -3 & -1.5 & $\begin{array}{l}-1 \\
-\end{array}$ & -2 \\
\hline tc_max_f & $\begin{array}{c}\text { I } \\
\text { II }\end{array}$ & $\begin{array}{l}\text { n.i. } \\
9\end{array}$ & $\begin{array}{l}\text { n.i. } \\
-\end{array}$ & $\begin{array}{l}\text { n.i. } \\
4.5\end{array}$ & $\begin{array}{l}\text { n.i. } \\
4.5\end{array}$ & $\begin{array}{l}\text { n.i. } \\
4.5\end{array}$ & $\begin{array}{l}\text { n.i. } \\
4.5\end{array}$ & $\begin{array}{l}\text { n.i. } \\
4.5\end{array}$ & $\begin{array}{l}\text { n.i. } \\
6\end{array}$ \\
\hline phenramp & $\begin{array}{c}\text { I } \\
\text { II }\end{array}$ & - & $\begin{array}{l}200 \\
150\end{array}$ & 100 & - & - & - & - & - \\
\hline longevity & $\begin{array}{c}\text { I } \\
\text { II }\end{array}$ & 50 & 200 & 500 & 500 & 500 & 500 & 500 & $\begin{array}{l}350 \\
450\end{array}$ \\
\hline k_allom 2 & & 5 & 40 & 40 & 40 & 22 & 30 & 40 & 40 \\
\hline tc_min_e & & - & - & -29 & -29 & -29 & -29 & -29 & -3.5 \\
\hline tc_min_s & & - & - & -30 & -30 & -30 & -30 & -30 & -4.5 \\
\hline ph.type & & $\mathrm{e}$ & $\mathrm{s}$ & $\mathrm{d}$ & $\mathrm{e}$ & $\mathrm{e}$ & $\mathrm{e}$ & $\mathrm{e}$ & $\mathrm{e}$ \\
\hline rootdist_u & & 0.8 & 0.8 & 0.6 & 0.8 & 0.6 & 0.6 & 0.6 & 0.8 \\
\hline rootdist_1 & & 0.2 & 0.2 & 0.4 & 0.2 & 0.4 & 0.4 & 0.4 & 0.2 \\
\hline leaflong & & 2 & 0.5 & 0.5 & 4 & 4 & 4 & 2 & 4 \\
\hline chill_b & & 100 & 400 & 100 & 100 & 100 & 100 & 100 & 100 \\
\hline cl.range & & $\mathrm{b}$ & $\mathrm{b}$ & $\mathrm{b}$ & b & $\mathrm{b}$ & $\mathrm{b}$ & b & $\mathrm{t}$ \\
\hline
\end{tabular}


Table D10. Continued.

\begin{tabular}{|c|c|c|c|c|c|c|c|c|c|}
\hline & & B.pen & C.bet & C.ave & F.syl & F.exc & Q.pub & Q.rob & T.cor \\
\hline shade tol. & & si & ist & si & st & ist & ist & ist & ist \\
\hline k_latosa & $\begin{array}{l}\text { I } \\
\text { II }\end{array}$ & 5000 & 5000 & 4000 & 5000 & 5000 & 4000 & $\begin{array}{l}4000 \\
4500\end{array}$ & 5000 \\
\hline d_tol & $\begin{array}{l}\text { I } \\
\text { II }\end{array}$ & $\begin{array}{l}0.42 \\
0.35\end{array}$ & 0.33 & 0.3 & $\begin{array}{l}0.3 \\
0.35\end{array}$ & 0.4 & 0.2 & $\begin{array}{l}0.25 \\
0.27\end{array}$ & 0.33 \\
\hline $\operatorname{gdd} 5 \mathrm{~min}$ & $\begin{array}{l}\text { I } \\
\text { II }\end{array}$ & 700 & 1200 & 800 & $\begin{array}{l}1500 \\
1300\end{array}$ & 1100 & 1900 & 1100 & 1000 \\
\hline tc_max_e & & - & - & - & - & - & - & - & - \\
\hline tc_max_f & $\begin{array}{l}\text { I } \\
\text { II }\end{array}$ & $\begin{array}{l}\text { n.i. } \\
-\end{array}$ & $\begin{array}{l}\text { n.i. } \\
-\end{array}$ & $\begin{array}{l}\text { n.i. } \\
-\end{array}$ & $\begin{array}{l}\text { n.i. } \\
-\end{array}$ & $\begin{array}{l}\text { n.i. } \\
-\end{array}$ & $\begin{array}{l}\text { n.i. } \\
-\end{array}$ & $\begin{array}{l}\text { n.i. } \\
-\end{array}$ & $\begin{array}{l}\text { n.i. } \\
-\end{array}$ \\
\hline phenramp & $\begin{array}{l}\text { I } \\
\text { II }\end{array}$ & $\begin{array}{l}200 \\
150\end{array}$ & 200 & 200 & 200 & 200 & 200 & 200 & 200 \\
\hline longevity & & 200 & 350 & 300 & 500 & 350 & 500 & 500 & 350 \\
\hline k_allom2 & & 40 & 40 & 40 & 40 & 40 & 40 & 40 & 40 \\
\hline tc_min_e & & -29 & -7 & -10 & -2.5 & -15 & -5 & -15 & -17 \\
\hline tc_min_s & & -30 & -8 & -11 & -3.5 & -16 & -6 & -16 & -18 \\
\hline ph.type & & $\mathrm{s}$ & $\mathrm{s}$ & $\mathrm{s}$ & $\mathrm{s}$ & $\mathrm{s}$ & $\mathrm{s}$ & $\mathrm{s}$ & $\mathrm{s}$ \\
\hline phenramp & & 100 & 200 & 200 & 200 & 200 & 200 & 200 & 200 \\
\hline longevity & & 200 & 350 & 300 & 500 & 350 & 500 & 500 & 350 \\
\hline rootdist_u & & 0.8 & 0.7 & 0.7 & 0.8 & 0.8 & 0.6 & 0.6 & 0.8 \\
\hline rootdist_1 & & 0.2 & 0.3 & 0.3 & 0.2 & 0.2 & 0.4 & 0.4 & 0.2 \\
\hline leaflong & & 0.5 & 0.5 & 0.5 & 0.5 & 0.5 & 0.5 & 0.5 & 0.5 \\
\hline chill_b & & 400 & 600 & 400 & 600 & 100 & 100 & 100 & 600 \\
\hline cl.range & & $\mathrm{t}$ & $\mathrm{t}$ & $\mathrm{t}$ & $\mathrm{t}$ & $\mathrm{t}$ & $\mathrm{t}$ & $\mathrm{t}$ & $\mathrm{t}$ \\
\hline
\end{tabular}




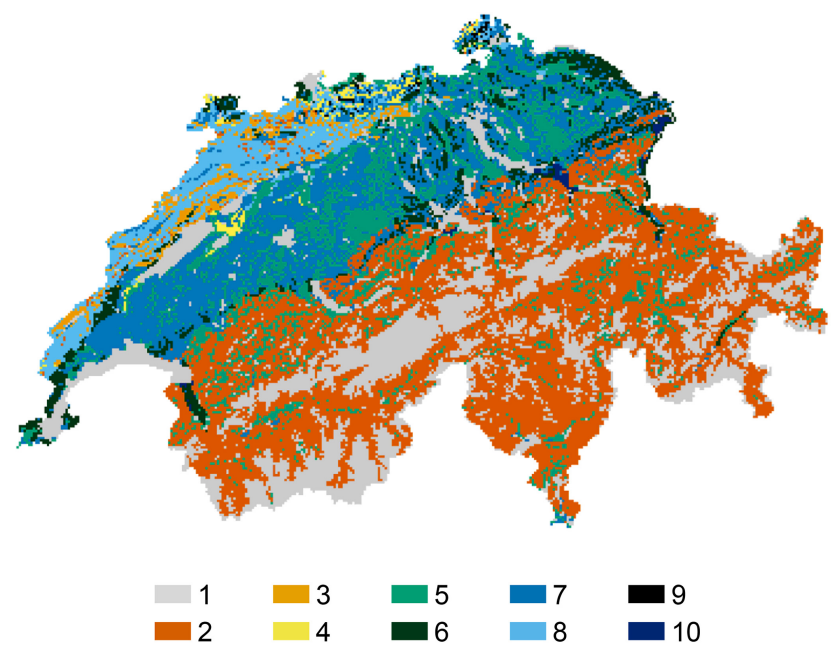

Figure D1. Soil code used in LPJ-GUESS simulations. 1 - urban, rocky or water areas (no forest growth); 2 - E: 5.0, V: 0.110, D0: 0.2, D15: 0.800, D100: 0.4; 3 - E: 4.0, V: 0.115, D0: 0.2, D15: 0.650, D100: 0.4; 4 - E: 4.0, V: 0.127, D0: 0.2, D15: 0.650, D100: 0.4; 5 - E: 4.5, V: 0.130, D0: 0.2, D15: 0.725, D100: 0.4; 6 - E: 4.0, V: 0.150, D0: 0.2, D15: 0.650, D100: 0.4; 7 - E: 3.5, V: 0.135, D0: 0.2, D15: 0.575, D100: 0.4; 8 - E: 3.0, V: 0.120, D0: 0.2, D15: 0.500, D100: 0.4; 9 - E: 0.2, V: 0.100, D0: 0.2, D15: 0.500, D100: 0.4, 10 - E: 9.0, V: 0.300, D0: 0.1, D15: 0.100, D100: 0.1. E: empirical parameter in percolation equation $(\mathrm{k} 1)\left(\mathrm{mm}^{\mathrm{day}}{ }^{-1}\right)$; V: volumetric water holding capacity at field capacity minus volumetric water holding capacity at wilting point, as fraction of soil layer depth; D0, D15 and D100: thermal diffusivity $\left(\mathrm{mm}^{2} \mathrm{~s}^{-1}\right)$ at 0,15 and $100 \%$ water holding capacity.

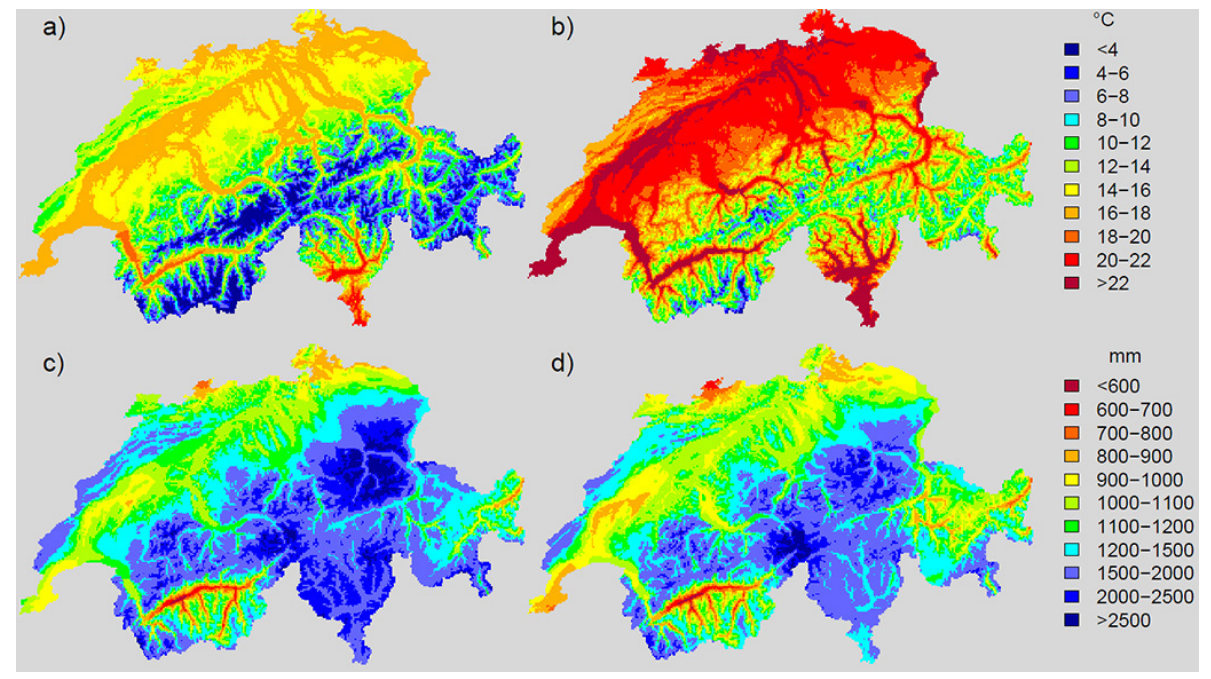

Figure D2. Development of temperature and precipitation over time under the SRES (Special Report on Emission Scenarios) A1B scenario used. (a) Mean summer temperature (June-July-August) for the 1900-1930 period; (b) mean summer temperature for the 2070-2100 period; (c) mean annual precipitation for the 1900-1930 period; (d) mean annual precipitation for the 2070-2100 period. 


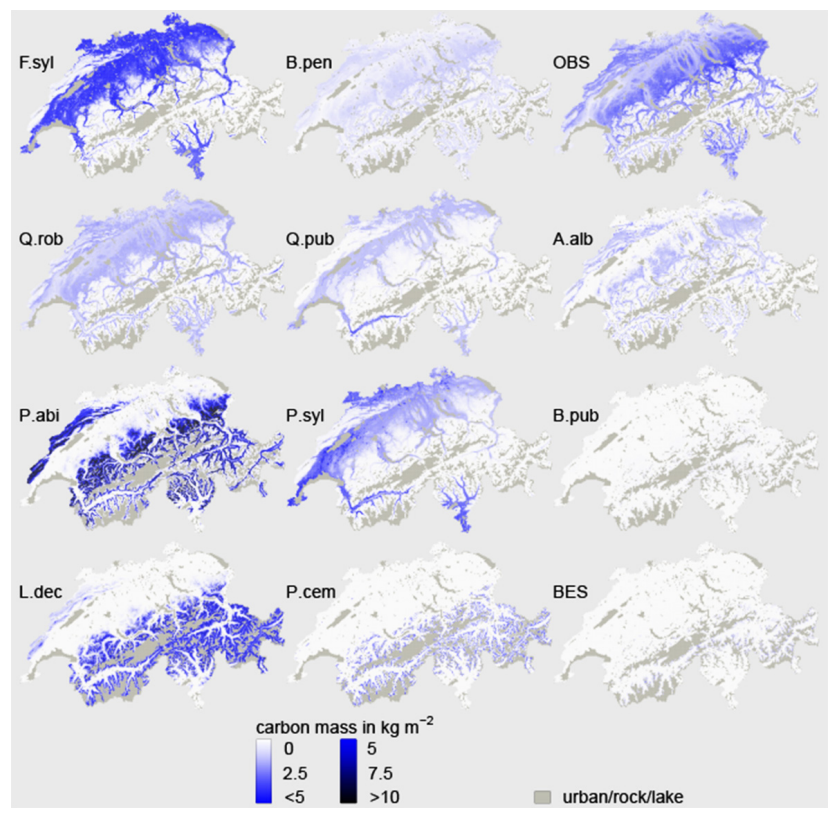

Figure D3. Carbon mass simulated with the adjusted parameter set for single species at 2100. A.alb: Abies alba; B.pen: Betula pendula; B. pub: Betula pubescens; F.syl: Fagus sylvatica; L.dec: Larix decidua; P.abi: Picea abies; P.cem: Pinus cembra; P.syl: Pinus sylvestris; Q.pub: Quercus pubescens; Q.rob: Quercus robur; BES: boreal evergreen shrubs; OBS: other broadleaved species.

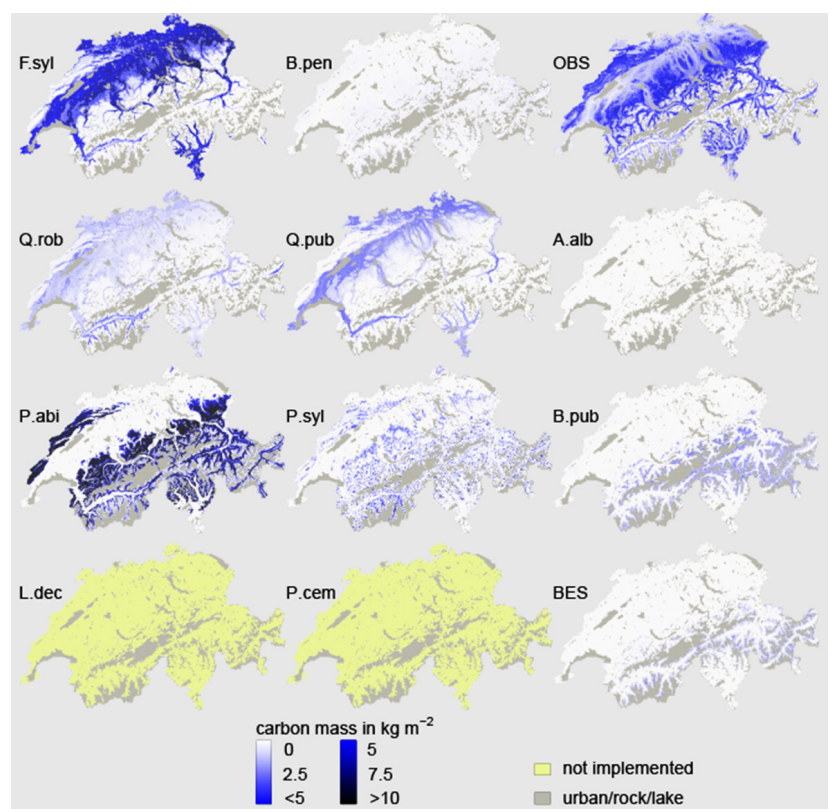

Figure D4. Carbon mass simulated with the standard parameter set for single species at 2100. See Fig. D3 for species abbreviations. 


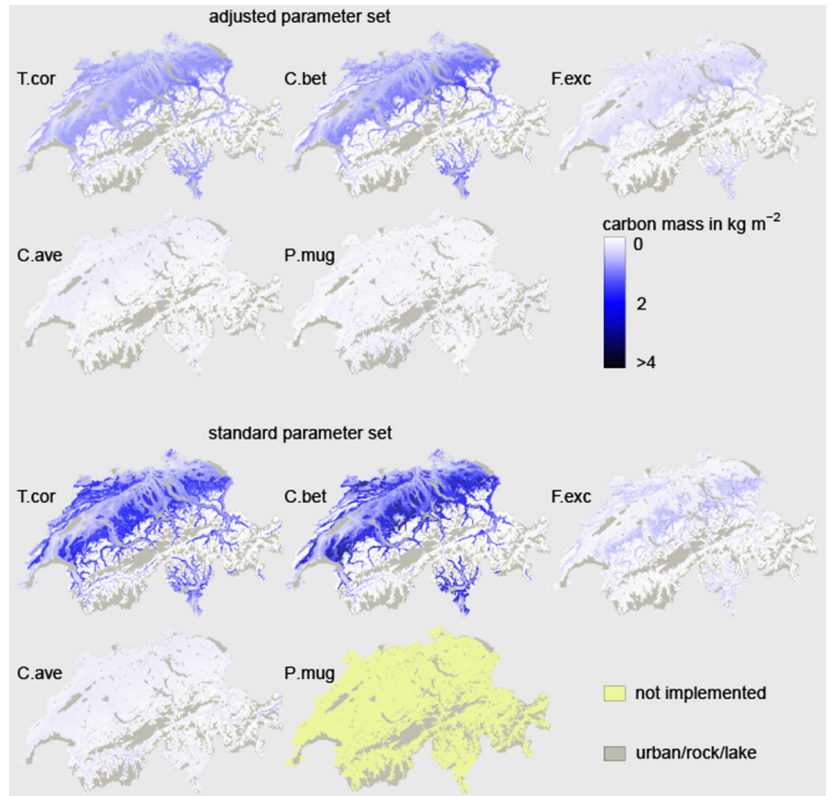

Figure D5. Carbon mass simulated with the adjusted and standard parameter set for minor species at 2000. C.bet: Carpinus betulus; C.ave: Corylus avellana; F.exc: Fraxinus excelsior; P.mug: Pinus mugo; T.cor: Tilia cordata. Please note that a different color gradient was used than in Fig. D3.

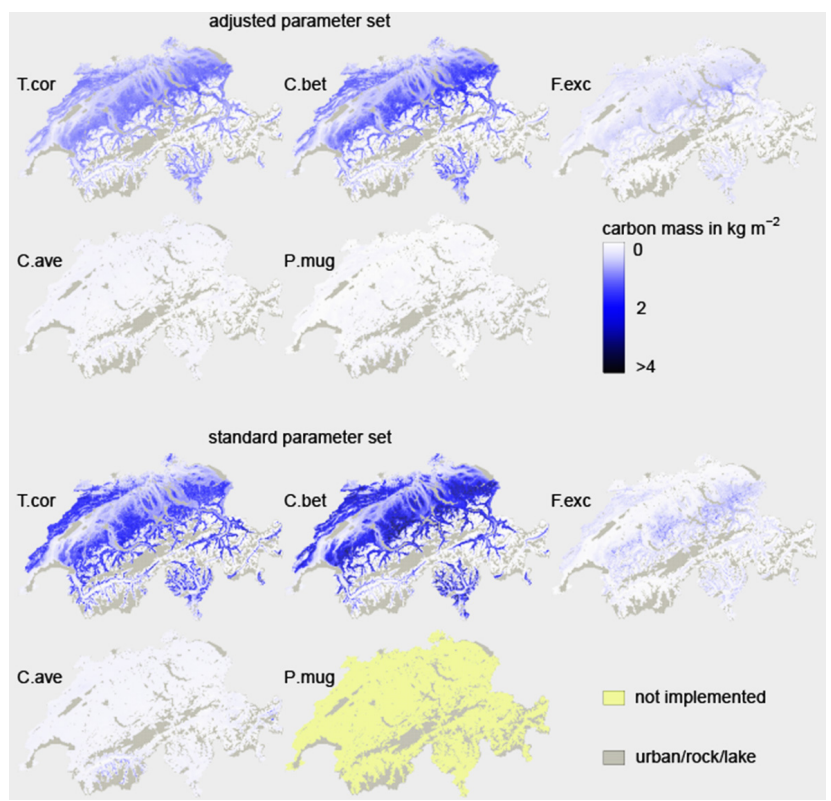

Figure D6. Carbon mass simulated with the adjusted and standard parameter set for minor species at 2100. See Fig. D5 for species abbreviations. Please note that a different color gradient was used than in Fig. D3. 


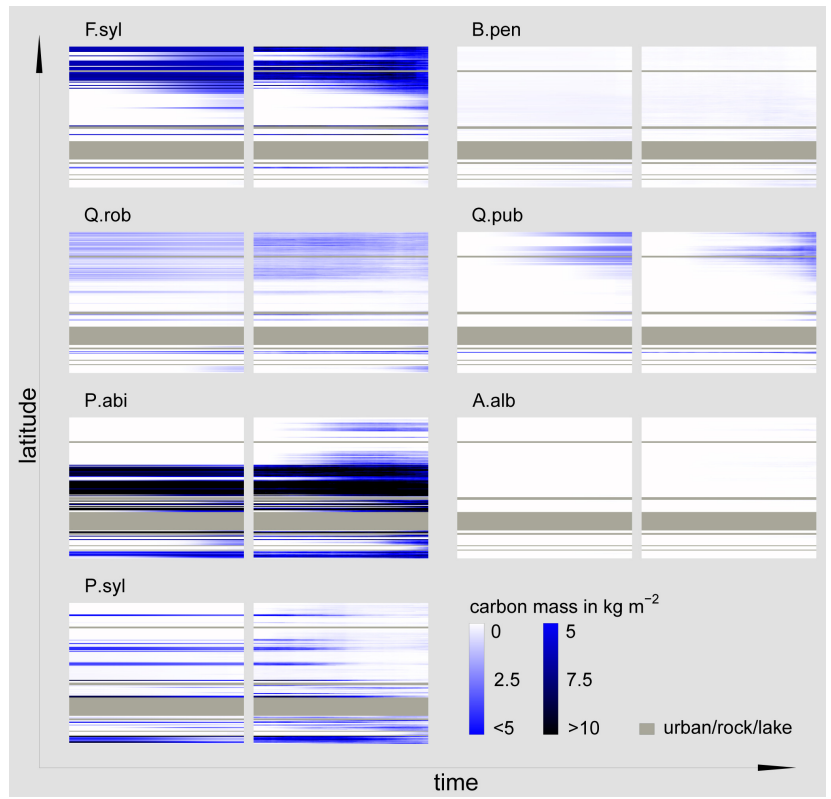

Figure D7. Carbon mass development along the analyzed transect of seven selected species using the stochastic (100 stochastic replicates) LPJ-GUESS approach (right) and the GAPPARD method (left), both with the standard parameter set. The timescale in each plot extends from 1900 (left side) to 2100 (right side). See Fig. D3 for species abbreviations.

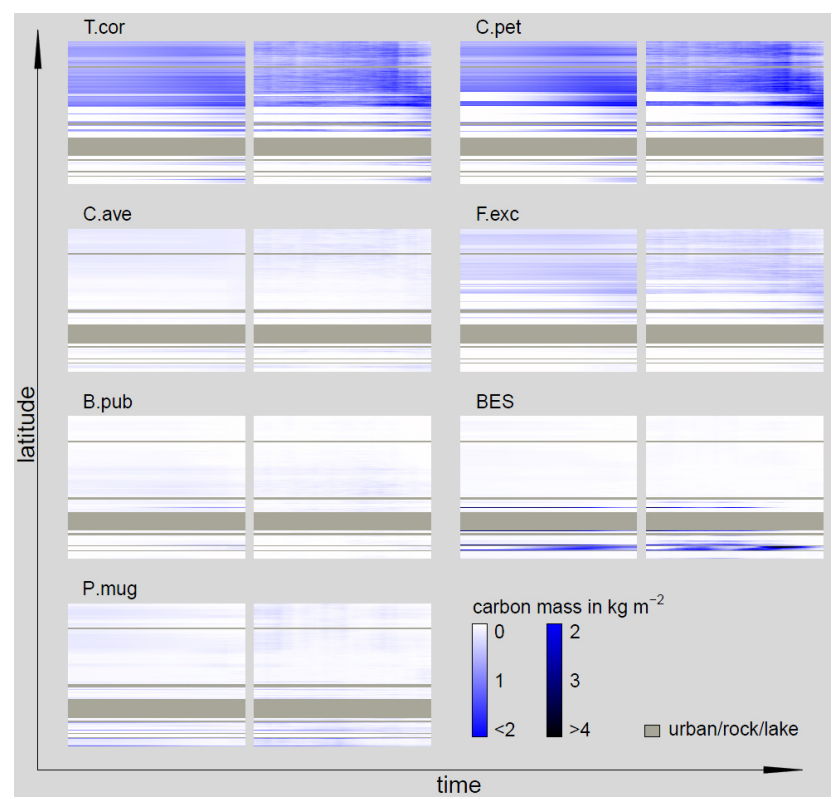

Figure D8. Carbon mass development of the minor species along the analyzed transect using the stochastic (100 stochastic replicates) LPJGUESS approach (right) and the GAPPARD method (left), both with the adjusted parameter set. The timescale in each plot extends from 1900 (left side) to 2100 (right side). See Fig. D3 for species abbreviations. Please note that a different color gradient was used than in Fig. D7. 


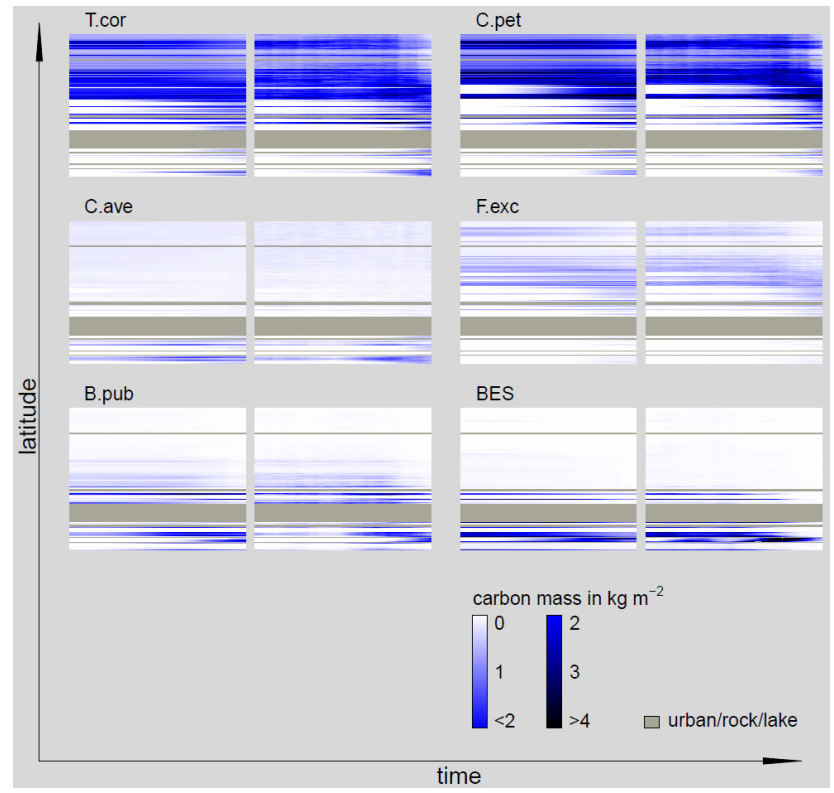

Figure D9. Carbon mass development of the minor species along the analyzed transect using the stochastic (100 stochastic replicates) LPJGUESS approach (right) and the GAPPARD method (left), both with the standard parameter set. The timescale in each plot extends from 1900 (left side) to 2100 (right side). See Fig. D3 for species abbreviations. Please note that a different color gradient was used than in Fig. D7. 
Acknowledgements. This study is part of the project SERC07.00123 (MEPHYSTO) funded by the Swiss COST office at the Swiss State Secretariat for Research and Education SBF and of the COST action FP0603: Forest models for research and decision support in sustainable forest management. Jed O. Kaplan was supported by the Swiss National Science Foundation (grants PP0022_119049 and PP00P2_139193). We thank Thomas Wuest for IT support and Dirk Schmatz for providing the downscaled climate data, Matthias Dobbertin and Andreas Rigling for information on forests in the Valais region and numerous colleagues who produced and provided the NFI data. The method development was inspired by discussions with Julia Nabel (Swiss National Science Foundation-project 315200_122434).

Edited by: H. Sato

\section{References}

Bohn, U., Gollub, G. C. H., Neuhäuslová, Z., Raus, T., Schlüter, H., and Weber, H.: Map of Natural Vegetation of Europe, Bonn: Federal Agency for nature conservation, 2004.

Bonan, G. B.: Forests and climate change: Forcings, feedbacks, and the climate benefits of forests, Science, 320, 1444-1449, 2008.

Botkin, D. B., Wallis, J. R., and Janak, J. F.: Some ecological consequences of a computer model of forest growth, J. Ecol., 60, 849-872, 1972.

Brändli, U.-B. (Ed.): Schweizerisches Landesforstinventar, Ergebnisse der dritten Erhebung 2004-2006, Birmensdorf, Eidgenössische Forschungsanstalt für Wald, Schnee und Landschaft, Bern, Bundesamt für Umwelt, Wald und Landschaft, 2009.

Brzeziecki, B., Kienast, F., and Wildi, O.: A simulated map of the potential natural forest vegetation of Switzerland, J. Veg. Sci., 4, 499-508, 1993.

Bugmann, H., Fischlin, A., and Kienast, F.: Model convergence and state variable update in forest gap models, Ecol. Model., 89, 197208, 1996.

Cheaib, A., Badeau, V., Boe, J., Chuine, I., Delire, C., Dufrene, E., Francois, C., Gritti, E. S., Legay, M., Page, C., Thuiller, W., Viovy, N., and Leadley, P.: Climate change impacts on tree ranges: model intercomparison facilitates understanding and quantification of uncertainty, Ecol. Lett., 15, 533-544, 2012.

Ellenberg, H.: Vegetation Mitteleuropas mit den Alpen in ökologischer Sicht, Verlag Eugen Ulmer, Stuttgart, 1986.

Epstein, H. E., Yu, Q., Kaplan, J. O., and Lischke, H.: Simulating future changes in Arctic and Subarctic vegetation, Comput. Sci. Eng., 9, 12-23, 2007.

Erb, K. H.: Land-use related changes in aboveground carbon stocks of Austria's terrestrial ecosystems, Ecosystems, 7, 563-572, 2004.

Falster, D. S., Brannstrom, A., Dieckmann, U., and Westoby, M.: Influence of four major plant traits on average height, leaf-area cover, net primary productivity, and biomass density in singlespecies forests: a theoretical investigation, J. Ecol., 99, 148-164, 2010.

Fischlin, A. and Midgley, G.: Ecosystems, their properties, goods and services, in: Climate Change 2007: Impacts, adaptation and vulnerability, Contributing of Working Group II to the Assess- ment Report Four of the Intergovernmental Panel of Climate Change (IPCC), edited by: Parry, M., Canziani, O., Palutikof, J., van der Lindenand, P., and Hanson, C., 211-272, Cambridge University Press, Cambridge, UK, 2007.

Fisher, R., McDowell, N., Purves, D., Moorcroft, P., Sitch, S., Cox, P., Huntingford, C., Meir, P., and Woodward, F. I.: Assessing uncertainties in a second-generation dynamic vegetation model caused by ecological scale limitations, New Phytol., 187, 666681, 2010.

Frehner, M., Wasser, B., and Schwitter, R.: Nachhaltigkeit und Erfolskontrolle im Schutzwald: Wegleitung für Pflegemassnahmen in Wäldern mit Schutzfunktion, BUWAL, Bern, 2005.

Frei, E.: Landwirtschafliche Bodeneignungskarte der Schweiz, Eidg. Drucksachen- und Materialzentrale, 1976.

Fulton, M. R.: Adult recruitment as a function of juvenile growthrate in size-structured plant-populations, Oikos, 62, 102-105, 1991.

Gimmi, U., Wolf, A., Burgi, M., Scherstjanoi, M., and Bugmann, H.: Quantifying disturbance effects on vegetation carbon pools in mountain forests based on historical data, Reg. Environ. Change, 9, 121-130, 2009.

Gritti, E. S., Smith, B., and Sykes, M. T.: Vulnerability of Mediterranean Basin ecosystems to climate change and invasion by exotic plant species, J. Biogeogr., 33, 145-157, 2006.

Hickler, T., Smith, B., Sykes, M. T., Davis, M. B., Sugita, S., and Walker, K.: Using a generalized vegetation model to simulate vegetation dynamics in northeastern USA, Ecology, 85, 519530, 2004.

Hickler, T., Smith, B., Prentice, I. C., Mjofors, K., Miller, P., Arneth, A., and Sykes, M. T.: $\mathrm{CO}_{2}$ fertilization in temperate FACE experiments not representative of boreal and tropical forests, Glob. Change Biol., 14, 1531-1542, 2008.

Hickler, T., Fronzek, S., Araujo, M. B., Schweiger, O., Thuiller, W., and Sykes, M. T.: An ecosystem model-based estimate of changes in water availability differs from water proxies that are commonly used in species distribution models, Global Ecol. Biogeogr., 18, 304-313, 2009.

Hickler, T., Vohland, K., Feehan, J., Miller, P. A., Smith, B., Costa, L., Giesecke, T., Fronzek, S., Carter, T. R., Cramer, W., Kuhn, I., and Sykes, M. T.: Projecting the future distribution of European potential natural vegetation zones with a generalized, tree species-based dynamic vegetation model, Global Ecol. Biogeogr., 21, 50-63, 2012.

IPCC: Climate Change 2001: The scientific basis. Contribution working group I to the third assessment report of the IPCC, Tech rep., Cambridge University Press, Cambridge, United Kingdom and New York, NY, USA, 2001.

Jury, W., Gardner, W., and Gardner, W.: Soil Physics, Vol. 5, John Wiley, New York, 1991.

Koca, D., Smith, B., and Sykes, M. T.: Modelling regional climate change effects on potential natural ecosystems in Sweden, Climatic Change, 78, 381-406, 2006.

Köhler, P. and Huth, A.: The effects of tree species grouping in tropical rainforest modelling: Simulations with the individual-based model FORMIND, Ecol. Model., 109, 301-321, 1998.

Kohyama, T.: Size-structured tree populations in gap-dynamic forest - the forest architecture hypothesis for the stable coexistence of species, J. Ecol., 81, 131-143, 1993. 
Kullman, L.: Tree line population monitoring of Pinus sylvestris in the Swedish Scandes, 1973-2005: implications for tree line theory and climate change ecology, J. Ecol., 95, 41-52, 2007.

Lischke, H.: Modeling tree species migration in the Alps during the Holocene: What creates complexity?, Ecol. Complex., 2, 159174, 2005.

Lischke, H., Zimmermann, N. E., Bolliger, J., Rickebusch, S., and Löffler, T. J.: TreeMig: A forest-landscape model for simulating spatio-temporal patterns from stand to landscape scale, Ecol. Model., 199, 409-420, 2006.

Manusch, C., Bugmann, H., Heiri, C., and Wolf, A.: Tree mortality in dynamic vegetation models - A key feature for accurately simulating forest properties, Ecol. Model., 243, 101-111, 2012.

Matías, L. and Jump, A. S.: Interactions between growth, demography and biotic interactions in determining species range limits in a warming world: The case of Pinus sylvestris, Forest Ecol. Manage., 282, 10-22, 2012.

Migliavacca, M., Cremonese, E., Colombo, R., Busetto, L., Galvagno, M., Ganis, L., Meroni, M., Pari, E., Rossini, M., Siniscalco, C., and di Cella, U. M.: European larch phenology in the Alps: can we grasp the role of ecological factors by combining field observations and inverse modelling?, Int. J. Biometeorol., 52, 587-605, 2008.

Mikola, J.: Provenance and individual variation in climatic hardiness of Scots Pine in Northern Finland, in: Forest Development in Cold Climates, edited by: Alden, J., Mastrantonio, J., and Odum, S., 333-342, Plenum Press, New York, 1993.

Miller, P. A., Giesecke, T., Hickler, T., Bradshaw, R. H. W., Smith, B., Seppa, H., Valdes, P. J., and Sykes, M. T.: Exploring climatic and biotic controls on Holocene vegetation change in Fennoscandia, J. Ecol., 96, 247-259, 2008.

Mitchell, T., Carter, R., Jones, P., Hulme, M., and New, M.: A comprehensive set of high-resolution grids of monthly climate for Europe and the globe: the observed record (1901-2000) and 16 scenarious (2001-2100), Tyndall Centre Working Paper No. 55, Norwich UK, 2004.

Moorcroft, P. R., Hurtt, G. C., and Pacala, S. W.: A method for scaling vegetation dynamics: The ecosystem demography model (ED), Ecol. Monogr., 71, 557-585, 2001.

Morales, P., Hickler, T., Rowell, D. P., Smith, B., and T Sykes, M.: Changes in European ecosystem productivity and carbon balance driven by regional climate model output, Glob. Change Biol., 13, 108-122, 2007.

Murray, M. B., Cannell, M. G. R., and Smith, R. I.: Date of budburst of 15 tree species in Britain following climatic warming, J. Appl. Ecol., 26, 693-700, 1989.

Neilson, R. P., Pitelka, L. F., Solomon, A. M., Nathan, R., Midgley, G. F., Fragoso, J. M. V., Lischke, H., and Thompson, K.: Forecasting regional to global plant migration in response to climate change, Bioscience, 55, 749-759, 2005.

Nienstaedt, H.: Chilling requirements in seven Picea species., Silvae Genet., 16, 65-68, 1967.

Oren, R., Whitehead, D., and Kaufmann, M. R.: Leaf area dynamics of coniferous forests, in: Ecophysiology of coniferous forests, edited by: Smith, W. K. and Hinckley, T. M., 181-233, Academic Press, San Diego, 1995.
Portner, H., Bugmann, H., and Wolf, A.: Temperature response functions introduce high uncertainty in modelled carbon stocks in cold temperature regimes, Biogeosciences, 7, 3669-3684, doi:10.5194/bg-7-3669-2010, 2010.

Prentice, I. C., Cramer, W., Harrison, S. P., Leemans, R., Monserud, R. A., and Solomon, A. M.: A global biome model based on plant physiology and dominance, soil properties and climate, J. Biogeogr., 19, 117-134, 1992.

Purves, D. and Pacala, S.: Predictive models of forest dynamics, Science, 320, 1452-1453, 2008.

Quillet, A., Peng, C., and Garneau, M.: Toward dynamic global vegetation models for simulating vegetation-climate interactions and feedbacks: recent developments, limitations, and future challenges, Environ. Rev., 18, 333-353, 2010.

Rehfeldt, G., Tchebakova, N., Milyutin, L., Parfenova, E., Wykoff, W., and Kouzmina, N.: Assessing population responses to climate in Pinus sylvestris and Larix spp. of Eurasia with climatetransfer models, Eurasian Journal of Forest Research, 6, 83-98, 2003.

Sato, H., Itoh, A., and Kohyama, T.: SEIB-DGVM: A new dynamic global vegetation model using a spatially explicit individualbased approach, Ecol. Model., 200, 279-307, 2007.

Scherstjanoi, M., Kaplan, J. O., Thürig, E., and Lischke, H.: GAPPARD: a computationally efficient method of approximating gap-scale disturbance in vegetation models, Geosci. Model Dev., 6, 1517-1542, doi:10.5194/gmd-6-1517-2013, 2013.

Shugart, H. H.: A theory of forest dynamics. The ecological implications of forest succession models, Springer, New York, 1984.

Sitch, S., Smith, B., Prentice, I. C., Arneth, A., Bondeau, A., Cramer, W., Kaplan, J. O., Levis, S., Lucht, W., Sykes, M. T., Thonicke, K., and Venevsky, S.: Evaluation of ecosystem dynamics, plant geography and terrestrial carbon cycling in the LPJ dynamic global vegetation model, Glob. Change Biol., 9, 161-185, 2003.

Smith, B., Prentice, I. C., and Sykes, M. T.: Representation of vegetation dynamics in the modelling of terrestrial ecosystems: comparing two contrasting approaches within European climate space, Glob. Ecol. Biogeogr., 10, 621-637, 2001.

Snell, R. S., Huth, A., Nabel, J. E. M. S., Bocedi, G., Travis, J. M. J., Gravel, D., Bugmann, H., Gutiérrez, A. G., Hickler, T., Higgins, S. I., Reineking, B., Scherstjanoi, M., Zurbriggen, N., and Lischke, H.: Using dynamic vegetation models to simulate plant range shifts, Ecography, online first, doi:10.1111/ecog.00580, 2014.

Sykes, M. T., Prentice, I. C., and Cramer, W.: A bioclimatic model for the potential distributions of north European tree species under present and future climates, J. Biogeogr., 23, 203-233, 1996.

Thornton, P. E., Running, S. W., and White, M. A.: Generating surfaces of daily meteorological variables over large regions of complex terrain, J. Hydrol., 190, 214-251, 1997.

van Duin, R. H. A.: The influence of soil management on the temperature wave near the surface, Institute for Land and Water Management Research, Wageningen, Netherlands, 1963.

von Foerster, H.: Some remarks on changing populations, Grune and Stratton, New York, 1959.

Walther, G.: Community and ecosystem responses to recent climate change, Philos. T. Roy. Soc. B, 365, 2019-2024, 2010. 
Wolf, A., Callaghan, T. V., and Larson, K.: Future changes in vegetation and ecosystem function of the Barents Region, Climatic Change, 87, 51-73, 2008.

Wolf, A., Lazzarotto, P., and Bugmann, H.: The relative importance of land use and climatic change in Alpine catchments, Climatic Change, 111, 279-300, 2012.
Wramneby, A., Smith, B., Zaehle, S., and Sykes, M. T.: Parameter uncertainties in the modelling of vegetation dynamics - Effects on tree community structure and ecosystem functioning in European forest biomes, Ecol. Model., 216, 277-290, 2008. 